\title{
Mercury dynamics in lake sediments
}

\author{
Stéphane Feyte ${ }^{\mathrm{a}}$, Charles Gobeil ${ }^{\mathrm{a}, \star}$, André Tessier $^{\mathrm{a}}$, Daniel Cossa ${ }^{\mathrm{b}}$ \\ a INRS-ETE, Université du Québec, 490 de la Couronne, Québec, QC, Canada G1K 9A9 \\ ${ }^{\mathrm{b}}$ Ifremer, Centre Méditerranée, BP330, 83507 La Seyne sur Mer, France \\ * : Corresponding author : \\ Tel.: +1 418654 2589; fax: +1 4186542600 . \\ E-mail address: Charles.Gobeil@ete.inrs.ca (C. Gobeil).
}

\begin{abstract}
:
Triplicate porewater depth-profiles of $\mathrm{pH}$ and concentrations of total $\mathrm{Hg}\left(\mathrm{Hg}_{T}\right)$, methylmercury $(\mathrm{MeHg}), \mathrm{Fe}, \mathrm{Mn}$, sulfate, total sulfide, total zero-valent sulfur, organic $\mathrm{C}$ and major ions were determined at two sampling dates in a perennially oxygenated basin and a seasonally anoxic basin from Lake Tantaré, a Canadian Shield lake. The vertical distribution of $\mathrm{Hg}_{T}, \mathrm{MeHg}$, acid volatile sulfide, total S, Fe, Mn, Al and organic C were also determined in dated sediment cores from the same lake basins and from the deepest site of two other lakes, one also located in the Canadian Shield and the other in the Northeastern part of the Appalachian Mountains. Application of a one-dimensional transport-reaction equation to the dissolved $\mathrm{Hg}_{T}$ and $\mathrm{MeHg}$ profiles constrains the depth intervals (zones) where these species are produced or consumed in the sedimentary column and yields estimates of net reaction rates of $\mathrm{Hg}_{T}$ or $\mathrm{MeHg}$ in each of the zones as well as their fluxes at the sediment-water interface.
\end{abstract}

Dissolved $\mathrm{Hg}_{\tau}$ and $\mathrm{MeHg}$ diffused from the overlying water into the sediments, except for $\mathrm{MeHg}$ at one of the sampling dates in the perennially oxygenated basin. About $97 \%$ and $50 \%$ of the MeHg flux to the sediments is presently deposited with settling particles in the perennially oxygenated and seasonally anoxic basins, respectively. Removal of porewater $\mathrm{Hg}_{\tau}$ and $\mathrm{MeHg}$ occurred at all dates and sampling sites. Comparison of the consumption zones of porewater $\mathrm{Hg}_{\tau}$ and $\mathrm{MeHg}$ with the profiles of ancillary parameters, coupled with thermodynamic calculations, suggest that pure $\mathrm{Hg}$ mineral phases do not form in the sediments, that $\mathrm{Hg}_{\tau}$ and MeHg adsorption onto authigenic Fe oxyhydroxides occurs in minor proportions, and that the association of $\mathrm{Hg}_{\tau}$ and $\mathrm{MeHg}$ to $\mathrm{Fe}$ sulfide phases or sulfidized organic matter is possible. Assuming that the net consumption of $\mathrm{MeHg}$ in the porewaters was essentially due to demethylation, an apparent first-order rate constant for $\mathrm{MeHg}$ demethylation of 0.04-0.8 $\mathrm{d}^{-1}$ was estimated. Production of porewater $\mathrm{MeHg}$ occurred only in the perennially oxygenated basin, at sediment depths where $\mathrm{SO}_{4}$ was consumed. Assuming that the net production of porewater $\mathrm{MeHg}$ was essentially due to methylation, an apparent first-order rate constant for $\mathrm{Hg}$ methylation ranging between $0.006 \mathrm{~d}^{-1}$ and $0.1 \mathrm{~d}^{-1}$ was calculated. These field-derived $\mathrm{Hg}$ methylation and $\mathrm{MeHg}$ demethylation rate constant values are within the range of those derived from $\mathrm{Hg}$-spiked experiments. We also show that the post-depositional redistribution of total $\mathrm{Hg}$ during the early stages of sediment diagenesis is minor and that the solid-phase $\mathrm{Hg}_{\tau}$ record can be used to reconstruct the evolution of the anthropogenic $\mathrm{Hg}_{T}$ deposition. 
1

2

3

4

5

6

7

8

9

10

11

12

13

14

$15 *$ Corresponding author. Fax: +1 4186542600

16 E-mail address: Charles.Gobeil@ete.inrs.ca

8

\title{
Mercury dynamics in lake sediments
}

\author{
Stéphane Feyte ${ }^{1}$, Charles Gobeil ${ }^{1, *}$, André Tessier $^{1}$, Daniel Cossa ${ }^{2}$
}

${ }^{1}$ INRS-ETE, Université du Québec, 490 de la Couronne, Québec, QC, Canada G1K 9 A9

${ }^{2}$ Ifremer, Centre Méditerranée, BP330, 83507 La Seyne sur Mer, France 
ABSTRACT

25

Triplicate porewater depth-profiles of $\mathrm{pH}$ and concentrations of total $\mathrm{Hg}\left(\mathrm{Hg}_{\mathrm{T}}\right)$, methylmercury (MeHg), Fe, Mn, sulfate, total sulfide, total zero-valent sulfur, organic $\mathrm{C}$ and major ions were determined at two sampling dates in a perennially oxygenated basin and a seasonally anoxic basin from Lake Tantaré, a Canadian Shield lake. The vertical distribution of $\mathrm{Hg}_{\mathrm{T}}, \mathrm{MeHg}$, acid volatile sulfide, total $\mathrm{S}, \mathrm{Fe}, \mathrm{Mn}, \mathrm{Al}$ and organic $\mathrm{C}$ were also determined in dated sediment cores from the same lake basins and from the deepest site of two other lakes, one also located in the Canadian Shield and the other in the Northeastern part of the Appalachian Mountains. Application of a one-dimensional transport-reaction equation to the dissolved $\mathrm{Hg}_{\mathrm{T}}$ and $\mathrm{MeHg}$ profiles constrains the depth intervals (zones) where these species are produced or consumed in the sedimentary column and yields estimates of net reaction rates of $\mathrm{Hg}_{\mathrm{T}}$ or $\mathrm{MeHg}$ in each of the zones as well as their fluxes at the sediment water-interface.

Dissolved $\mathrm{Hg}_{\mathrm{T}}$ and $\mathrm{MeHg}$ diffused from the overlying water into the sediments, except for $\mathrm{MeHg}$ at one of the sampling dates in the perennially oxygenated basin. About $97 \%$ and $50 \%$ of the $\mathrm{MeHg}$ flux to the sediments is presently deposited with settling particles in the perennially oxygenated and seasonally anoxic basins, respectively. Removal of porewater $\mathrm{Hg}_{\mathrm{T}}$ and $\mathrm{MeHg}$ occurred at all dates and sampling sites. Comparison of the consumption zones of porewater $\mathrm{Hg}_{\mathrm{T}}$ and $\mathrm{MeHg}$ with the profiles of ancillary parameters, coupled with thermodynamic calculations, suggest that pure $\mathrm{Hg}$ mineral phases do not form in the sediments, that $\mathrm{Hg}_{\mathrm{T}}$ and $\mathrm{MeHg}$ adsorption onto authigenic Fe oxyhydroxides occurs in minor proportions, and that the association of $\mathrm{Hg}_{\mathrm{T}}$ and $\mathrm{MeHg}$ to Fe sulfide phases or sulfidized organic matter is possible. Assuming that the net 
consumption of $\mathrm{MeHg}$ in the porewaters was essentially due to demethylation, an apparent firstorder rate constant for MeHg demethylation of 0.04-0.8 $\mathrm{d}^{-1}$ was estimated. Production of porewater $\mathrm{MeHg}$ occurred only in the perennially oxygenated basin, at sediment depths where $\mathrm{SO}_{4}$ was consumed. Assuming that the net production of porewater $\mathrm{MeHg}$ was essentially due to methylation, an apparent first-order rate constant for $\mathrm{Hg}$ methylation ranging between $0.006 \mathrm{~d}^{-1}$ and $0.1 \mathrm{~d}^{-1}$ was calculated. These field-derived $\mathrm{Hg}$ methylation and $\mathrm{MeHg}$ demethylation rate constant values are within the range of those derived from $\mathrm{Hg}$-spiked experiments. We also show that the post-depositional redistribution of total $\mathrm{Hg}$ during the early stages of sediment diagenesis is minor and that the solid-phase $\mathrm{Hg}_{\mathrm{T}}$ record can be used to reconstruct the evolution of the anthropogenic $\mathrm{Hg}_{\mathrm{T}}$ deposition.

1

$$
\text { stimulated the in situ production of methylmercury }(\mathrm{MeHg}) \text { in aquatic systems and the }
$$
incorporation of this neurotoxic compound into food chains (Evers et al., 1998; Hammerschmidt and Fitzgerald, 2006b; Munthe et al., 2007). The potential harmful consequences for human health and wildlife and possible adverse economical effects on the fishing industry raised by this issue have led to a marked interest over recent years for unraveling $\mathrm{Hg}$ cycling in aquatic systems (Fitzgerald et al., 2007). This study is in line with this general objective; it focuses on $\mathrm{Hg}$ dynamics in recent sediment deposits which are considered to be a key location for $\mathrm{MeHg}$ formation (Krabbenhoft et al., 1998; Kainz et al., 2003; Hammerschmidt et al., 2006). 
Current inferences on in situ $\mathrm{Hg}_{\mathrm{T}}$ and $\mathrm{MeHg}$ mobility and on the processes involving these species in modern sediments are mostly derived from measurements in the solid phase alone

72 (Lockhart et al., 2000; Rydberg et al., 2008) or from laboratory experiments involving bacterial

cultures (Compeau and Bartha, 1985) or incubations of $\mathrm{Hg}$-spiked pure solid phases, sediments or lake water (Gunneriusson et al., 1995; Tiffreau et al., 1995; Miller, 2006; Ramlal et al., 1986;

Hintelmann et al., 2000; Eckley et al., 2005). We submit that measuring $\mathrm{Hg}_{\mathrm{T}}, \mathrm{MeHg}$ and ancillary parameters in sediments and porewaters, combined with thermodynamic and kinetic modeling, provides an alternative to constrain in situ $\mathrm{Hg}_{\mathrm{T}}$ and $\mathrm{MeHg}$ mobility, physico-chemical processes involving $\mathrm{Hg}_{\mathrm{T}}$ and $\mathrm{MeHg}$ and their reaction kinetics. Although porewaters are sensitive indicators of reactions that occur in the solid phase, most studies reporting porewater profiles of $\mathrm{Hg}_{\mathrm{T}}$ and MeHg, with a few exceptions (Goulet et al., 2007; Merritt and Amirbahman, 2007, 2008), only provided a qualitative interpretation of their results.

\section{METHODS}

In this paper, the concentrations of dissolved and solid-phase species $\mathrm{X}$ are designated by [X] and $\{\mathrm{X}\}$, respectively. We assume that dissolved non-methylated $\mathrm{Hg}$ concentration $\left(\left[\mathrm{Hg}_{\mathrm{NM}}\right]\right)$ is the difference between dissolved total $\mathrm{Hg}\left(\left[\mathrm{Hg}_{\mathrm{T}}\right]\right)$ and dissolved monomethylmercury $([\mathrm{MeHg}])$ concentrations.

\subsection{Study areas}

Three oligotrophic headwater lakes (Tantaré, Bédard and Holland) located in the Province of Québec (Eastern Canada) were investigated (Fig. 1). Their geographical coordinates, geological setting, altitude, water column $\mathrm{pH}$, hypolimnetic oxygenation conditions as well as their surface 
93

and watershed areas are given in Table 1. The only inputs of anthropogenic $\mathrm{Hg}$ into these lakes are from atmospheric deposition since their watersheds have never been inhabited; the watersheds have also not been affected by wildfire or lumbering, except that of Lake Bédard where tree cutting occurred several decades ago. Lakes Tantaré and Bédard are situated within $50 \mathrm{~km}$ of Québec City ( 500,000 inhabitants), in a Provincial ecological reserve and in the protected Montmorency Forest, respectively. In Lake Tantaré, two adjacent basins separated by a shallow sill ( 2 m) have been sampled: Basin A is $15 \mathrm{~m}$ deep and Basin B, which is upstream from Basin A (see Fig. 1), is $22 \mathrm{~m}$ deep. Both Basins A and B develop a thermal stratification which shifts from about $4 \mathrm{~m}$ depth at the end of May to $10 \mathrm{~m}$ depth at the end of October. The hypolimnion of Basin $\mathrm{B}$, in contrast to that of Basin A, becomes anoxic $\left(\left[\mathrm{O}_{2}\right]\left(<0.01 \mathrm{mg} \mathrm{L}^{-1}\right)\right.$ by mid-summer. Lake Holland is situated in the Gaspé Peninsula, $8 \mathrm{~km}$ from Murdochville, a small city $(<3,000$ inhabitants) where a non-ferrous metal smelter (103,000 T of copper/zinc and 164,600 $\mathrm{T}$ of sulfuric acids produced in 1995; Newhook et al., 2003) operated from 1951 to 2002. Maximum depths in Lakes Bédard and Holland are 10 and 11 m, respectively.

\subsection{Sampling}

Sediment cores were collected by divers with $9.5-\mathrm{cm}$ internal diameter butyrate tubes at the deepest site of each lake or basin between June 2003 and June 2006 (Table 1). The cores were extruded on shore and sectioned at $0.5-\mathrm{cm}$ intervals from the sediment surface to $10 \mathrm{~cm}$ or $15 \mathrm{~cm}$ depth and then at $1-\mathrm{cm}$ intervals to $30 \mathrm{~cm}$ depth. The sediment samples for subsequent acid volatile sulfide (AVS) measurements were individually sealed in plastic bags that were put into a larger 
115 bag filled with anoxic sediment to prevent their oxidation, whereas those for all other

116 measurements were kept in polyethylene containers.

117

118 Sheets of skived Teflon $(7 \times 15 \mathrm{~cm})$ that had been inserted by divers across the sediment-water

119 interface at the sampling site of Lake Tantaré Basin A in October 1993 were retrieved in August

1202006 , rinsed with lake water to remove living animals and sediment particles and stored in

121 polyethylene containers. During the 13-yr deployment, authigenic Fe oxyhydroxides (Fe-ox) that

122 are normally deposited onto sediment particles close to oxygenated sediment surface were

123 collected by the Teflon sheets inserted in the sediments (Belzile et al., 1989). Fe-ox particles

124 previously collected in this lake by the same technique were identified as poorly crystalline

125 ferrihydrite and lepidocrocite by Fortin et al. (1993), using electron microscopy and X-ray

126 diffraction. Authigenic Mn oxyhydroxides do not form in the sediments of this lake (see section

127 3.2) and thus, the material collected on Teflon sheets can be qualified as Fe-rich authigenic 128 material.

Porewater samples were collected by in situ dialysis (Carignan et al., 1994) from $5 \mathrm{~cm}$ above

131 the sediment-water interface to $10 \mathrm{~cm}$ below in the two basins of Lake Tantaré. The peepers used

132 had two columns of 4-mL cells with a 1-cm vertical resolution. They were acid-washed and stored

133 under nitrogen for at least two weeks. The cells were then filled with ultrapure water $(>18 \mathrm{M} \Omega$

$134 \mathrm{~cm}$ ) and covered with a pre-cleaned $0.2 \mu \mathrm{m}$ nominal pore size polysulfone membrane (HT-200,

135 Gelman). The assembled peepers were kept again under nitrogen for about two weeks, until their

136 deployment. Twelve peepers were deployed by divers within an area of about $25 \mathrm{~m}^{2}$ around the

137 coring site in September 2005 and September 2006 in Basin A, which remains perennially oxic 
$138\left(\left[\mathrm{O}_{2}\right]>4 \mathrm{mg} \mathrm{L}^{-1}\right)$, and in September 2006 and July 2007 in Basin B, when the bottom water was

139 anoxic $\left(\left[\mathrm{O}_{2}\right]<0.01 \mathrm{mg} \mathrm{L}^{-1}\right)$ and oxic $\left(\left[\mathrm{O}_{2}\right]>4 \mathrm{mg} \mathrm{L}^{-1}\right)$, respectively. Three peepers were sampled

140 to obtain triplicate measurements of $\mathrm{pH}$ and concentrations of dissolved organic carbon ([DOC]),

141 total sulfide $\left(\sum \mathrm{S}(-\mathrm{II})\right)$, total zero-valent sulfur $\left(\sum \mathrm{S}(0)\right)$ and major anions. Water from the remaining

142 nine peepers was collected as follow in order to get three 24-mL samples for each sampling depth

143 for subsequent measurements of $\mathrm{Hg}_{\mathrm{T}}, \mathrm{MeHg}$ and major cations ( $\mathrm{Al}, \mathrm{Ca}, \mathrm{Fe}, \mathrm{K}, \mathrm{Mg}, \mathrm{Mn}$ and $\mathrm{Na}$ ).

144 Water in the cells positioned at a given height above or below the sediment-water interface was

145 collected from three peepers by piercing the polysulfone membrane with an acid-cleaned plastic tip

146 fitted to a Gilson pipette and was pooled in previously acid-washed Teflon (PFA) bottles. After

147 shaking, a 1-mL aliquot was removed and transferred to a pre-acidified $(10 \mu \mathrm{L}$ of $2 \mathrm{~N}$ ultra clean

$148 \mathrm{HNO}_{3}$ ) vial for the measurements of the cations. The remaining $23-\mathrm{mL}$ sample was acidified by

149 adding $115 \mu \mathrm{L}$ of ultra clean concentrated $\mathrm{HCl}$ to the Teflon bottle, which was then sealed in

150 double plastic bags. To obtain sampling procedural blanks for $\left[\mathrm{Hg}_{\mathrm{T}}\right],[\mathrm{MeHg}], \sum \mathrm{S}(-\mathrm{II}), \Sigma \mathrm{S}(0)$ and

151 DOC, ultrapure water was processed at the sampling site similarly to the porewater samples.

152

153 2.3. Analyses

154

155 The method used to measure $\left[\mathrm{Hg}_{\mathrm{T}}\right]$ was modified from Bloom and Fitzgerald (1988). It is

156 similar to standard method No. 1631 from US EPA (USEPA, 2002). Briefly, [ $\left.\mathrm{Hg}_{\mathrm{T}}\right]$ was

157 determined by cold vapor atomic fluorescence spectrometry (CVAFS; Tekran® model 2500),

158 using external calibration after successive addition of $\mathrm{BrCl}$ to release $\mathrm{Hg}(\mathrm{II})$ from organic ligands,

159 and $\mathrm{SnCl}_{2}$, to reduce $\mathrm{Hg}(\mathrm{II})$ to elemental $\mathrm{Hg}(\mathrm{Hg}(0))$, which was concentrated by gold

160 amalgamation prior to CVAFS detection. Detection limit (DL), which was determined daily as 3.3 
161 times the standard deviation (SD) of analytical procedural blanks, was between 0.5 and $2 \mathrm{pM}$ for a

$16210-\mathrm{mL}$ water sample. Precision, determined from replicate measurements $(\mathrm{n}=6)$, was better than

$1635 \%$ at $20 \mathrm{pM}$ and $15 \%$ at $1 \mathrm{pM}$. Analytical accuracy was checked every day with the reference

164 material ORMS-3 from the National Research Council of Canada (NRCC). Dissolved MeHg,

165 which is not degraded during long-term storage (at least 250 days; Parker and Bloom, 2005), was

166 measured within 2-4 weeks after sample collection. It was converted to volatile methylmercury

167 hydride, separated by purge and cryo-trapping gas chromatography, and detected as $\mathrm{Hg}(0)$ by

168 CVAFS (Tekran Model 2500). The hydride generation technique used was that proposed by

169 Stoichev et al. (2004) and optimized by Cossa et al. (2009). Daily DL varied between $0.05 \mathrm{pM}$ and

$1700.2 \mathrm{pM}$. Precision, determined from replicate samples $(\mathrm{n}=6)$, was $6 \%$ at a $[\mathrm{MeHg}]$ of $0.5 \mathrm{pM}$.

171 Accuracy was checked using the certified reference material ERM-AE70 from the Institute for

172 Reference Materials and Measurements (IRMM, European Commission).

173

174 Solid-phase $\mathrm{Hg}_{\mathrm{T}}$ was determined on 50-mg freeze-dried sediment aliquots using a mercury

175 analyzer (Milestone DMA-80). This method, also known as the US EPA standard method No.

1767473 (USEPA, 2007), includes a pyrolysis step that releases $\mathrm{Hg}$, which is then concentrated by $\mathrm{Au}$

177 amalgamation and detected by atomic absorption spectrometry (Cossa et al., 2002). Detection limit

178 (3.3 SD of blanks) was $30 \mathrm{pmol} \mathrm{g}^{-1}$. Precision, determined from replicate measurements $(\mathrm{n}=10)$ of

179 a sediment sample was better than 5\%. Accuracy, determined with the reference sediment MESS-3

180 from NRCC, was better than 5\%. Solid-phase MeHg was only determined for Lake Tantaré

181 sediments and two different analytical methods were used. The method of Leermakers et al. (2001)

182 adapted by Cossa et al. (2002) was used to analyze Basin A samples. MeHg was released from

183 about 200-mg aliquots of freeze-dried sediments with $\mathrm{HNO}_{3}(4 \mathrm{~N})$, extracted with $\mathrm{CH}_{2} \mathrm{Cl}_{2}$ and 
184 transferred into $40 \mathrm{~mL}$ of ultrapure water. After evaporation of the organic solvent, $\mathrm{MeHg}$ in the 185 water phase was ethylated and purged on a Tenax-packed column. Ethylmethylmercury was then 186 isolated from other volatile compounds by gas chromatography and quantified by CVAFS.

187 Detection limit (3.3 SD of blanks) was $0.1 \mathrm{pmol} \mathrm{g}^{-1}$ and analytical precision was better than $15 \%$. $188 \mathrm{MeHg}$ analysis of the CRM 405 material from the International Atomic Energy Agency (IAEA) 189 yielded a recovery of $91 \pm 8 \%$. The method used to analyze Basin B samples was based on the 190 separation of organomercurials by gas chromatography, followed by ionisation of analytes in argon 191 plasma and $\mathrm{Hg}$ detection by mass spectrometry (Leermakers et al., 2005). Briefly, a known 192 quantity of an internal standard $\left(\mathrm{Me}^{202} \mathrm{Hg}\right)$ was added to an aliquot of freeze-dried sediment which 193 was then leached with $4 \mathrm{~mL}$ of $\mathrm{HNO}_{3}(6 \mathrm{~N})$. After centrifugation and decantation, the $\mathrm{pH}$ was 194 adjusted to 4 by adding ammonia and a sodium acetate-acetic acid buffer. MeHg was then 195 propylated by adding sodium tetrapropylborate and the $\mathrm{Hg}$ compound was extracted in isooctane. 196 The analysis of propylated $\mathrm{MeHg}$ was performed by gas chromatography coupled to a quadrupole 197 ICP-MS. Detection limit was around $1 \mathrm{pmol} \mathrm{g}^{-1}$. Precision, determined from replicate 198 measurements $(n=6)$ of the CRM 405 material from IAEA, was better than $10 \%$ and the recovery 199 was evaluated to $102 \%$.

Porewater $\mathrm{Fe}, \mathrm{Mn}, \mathrm{Ca}, \mathrm{K}, \mathrm{Mg}$ and $\mathrm{Na}$ concentrations were obtained by inductively coupled 201 plasma optical emission spectroscopy (ICP-OES; VISTA AX CCD) using external calibration.

202 Sulfate was measured by ion chromatography, dissolved inorganic C by gas chromatography, 203 dissolved organic C with a Shimadzu carbon analyzer, $\Sigma$ S(-II) by colorimetry within $48 \mathrm{~h}$ of 204 sample collection and $\Sigma \mathrm{S}(0)$ by square-wave cathodic stripping voltammetry (Wang et al., 1998). It should be noted that $\Sigma \mathrm{S}(-\mathrm{II})$ and $\Sigma \mathrm{S}(0)$ are defined as (Wang and Tessier, 2009): $\Sigma \mathrm{S}(-\mathrm{II})=\left[\mathrm{H}_{2} \mathrm{~S}\right]+$ 206 $\left[\mathrm{HS}^{-}\right]+\Sigma\left[\mathrm{H}_{x} \mathrm{~S}_{n} \mathrm{~S}^{x-2}\right]$ and $\Sigma \mathrm{S}(0)=\left[\mathrm{S}(0)_{(\mathrm{aq})}\right]+\Sigma n\left[\mathrm{H}_{x} \mathrm{~S}_{n} \mathrm{~S}^{x-2}\right]$, where $x(0-2)$ and $n(1-7)$ are the 
numbers of $\mathrm{H}$ and zero-valent $\mathrm{S}$ atoms in the polysulfide species $\mathrm{H}_{x} \mathrm{~S}_{n} \mathrm{~S}^{x-2}$, respectively, and $\mathrm{S}(0)_{(\mathrm{aq})}$ is the free dissolved zero-valent sulfur.

The analytical protocols for the measurements of solid-phase $\mathrm{Al}, \mathrm{Fe}, \mathrm{Mn}$, organic $\mathrm{C}\left(\mathrm{C}_{\mathrm{org}}\right)$, total $\mathrm{S}\left(\mathrm{S}_{\mathrm{T}}\right)$, AVS, ${ }^{210} \mathrm{~Pb},{ }^{214} \mathrm{~Pb}$ and ${ }^{137} \mathrm{Cs}$ are described by Chappaz et al. (2008). Briefly, $\mathrm{C}_{\mathrm{org}}$ concentration was determined using a NCS Carbo Erba analyzer. Aliquots of sediments were

212 totally digested with $\mathrm{HNO}_{3}, \mathrm{HClO}_{4}$ and $\mathrm{HF}$ and $\mathrm{Fe}, \mathrm{Mn}, \mathrm{Al}$ and $\mathrm{S}_{\mathrm{T}}$ concentrations were determined 213 by ICP-OES. AVS concentrations were determined by acidification of wet sediments with $6 \mathrm{~N}$ $214 \mathrm{HCl}$, and the sulfide released was trapped in a $\mathrm{NaOH}$ solution and measured by colorimetry. For 215 sediment dating, dried sediment aliquots were placed in sealed vials for at least 1 month to achieve 216 secular equilibrium of ${ }^{222} \mathrm{Rn}$ and ${ }^{214} \mathrm{~Pb}$ with ${ }^{226} \mathrm{Ra}$, and the activities of ${ }^{137} \mathrm{Cs},{ }^{210} \mathrm{~Pb}$ and ${ }^{214} \mathrm{~Pb}$ were 217 measured by gamma spectrometry (Chappaz et al., 2008). Unsupported ${ }^{210} \mathrm{~Pb}$ activity was obtained 218 by subtracting ${ }^{214} \mathrm{~Pb}$ activity from that of ${ }^{210} \mathrm{~Pb}$. The ${ }^{210} \mathrm{~Pb}$ models used to determine sediment mass 219 accumulation rates $\left(\omega, \mathrm{mg} \mathrm{cm}^{-2} \mathrm{yr}^{-1}\right)$ and sediment ages are given by Couture et al. (2008, 2010a).

Areas of the Teflon sheets containing the Fe-rich authigenic deposits were cut and dissolved in $50 \% \mathrm{HCl}$ for $48 \mathrm{~h}$ at room temperature. The resulting solutions were filtered through $0.4-\mu \mathrm{m}$ pore size Teflon membranes, diluted 10 times and analyzed for Fe by inductively coupled plasma optical emission spectroscopy (ICP-OES; VISTA AX CCD), for C and N with a Shimadzu C N analyzer and for $\mathrm{Hg}_{\mathrm{T}}$ and $\mathrm{MeHg}$ as described above for dissolved $\mathrm{Hg}_{\mathrm{T}}$ and $\mathrm{MeHg}$.

\subsection{Calculations of chemical speciation}


The speciation of $\mathrm{Hg}$ in porewater and overlying water was predicted with the computer code

230

231

232

233

234

235

236

237

238

239

240

241

242

243

244

245

246

247

248

249

250

251

Windermere Humic Aqueous Model (WHAM 6; Tipping, 2002) using as inputs the average measured $\mathrm{pH}$ values and concentrations of dissolved $\mathrm{Hg}_{\mathrm{NM}}, \mathrm{MeHg}, \mathrm{Al}, \mathrm{Ca}, \mathrm{Fe}, \mathrm{K}, \mathrm{Mg}, \mathrm{Mn}, \mathrm{Na}, \mathrm{Cl}$, $\mathrm{SO}_{4}, \mathrm{CO}_{3}, \Sigma \mathrm{S}(-\mathrm{II}), \Sigma \mathrm{S}(0)$, and humic (HA) and fulvic (FA) acids. The concentrations of $\mathrm{HA}$ and FA were calculated from those of DOC, assuming that dissolved organic matter contains $50 \%$ of $\mathrm{C}$ (Buffle, 1988) and that all DOC is humic substances with a ratio [FA]:[HA] of 9:1 (Malcolm, 1985). We updated the thermodynamic database of WHAM 6 with the thermodynamic constants for the reactions of $\mathrm{Hg}$ and $\mathrm{MeHg}$ listed in Table 2, which required adding $\mathrm{MeHg}$ and dissolved zero-valent $\mathrm{S}\left(\mathrm{S}(0)_{\mathrm{aq}}\right)$ as new components. To be compatible with the code format, all reactions expressed in terms of solid rhombic sulfur $\left(S(\alpha)_{8(s)}\right)$ in the literature were rewritten in terms of $\mathrm{S}(0)_{\mathrm{aq}}$ assuming that $1 / 8 \mathrm{~S}(\alpha)_{8(\mathrm{~s})}=\mathrm{S}(0)_{\mathrm{aq}} ; \mathrm{K}_{\mathrm{S}}=10^{-6.68}$ (Wang and Tessier, 2009). The constants for the formation of $\mathrm{Hg}$-sulfide and $\mathrm{Hg}$-polysulfide complexes were those provided by Jay et al. (2000), whereas those for the formation of $\mathrm{Hg}$ and $\mathrm{MeHg}$ complexes with HA and FA were recently updated by Tipping (2007). However, some of the constants should be taken with caution, especially those for the formation of $\mathrm{Hg}$ and $\mathrm{MeHg}$ complexes with sulfide, polysulfides, and humic and fulvic acids. For instance, it is noteworthy that the species $\mathrm{HgS}_{(\mathrm{aq})}$ has never been detected experimentally. For the formation of the $\mathrm{HgS}_{\mathrm{y}} \mathrm{OH}^{-}$and $\mathrm{Hg}\left(\mathrm{S}_{\mathrm{y}}\right)_{2}{ }^{2-}$ complexes given by Jay et al. (2000), the value of $y$, which could not be specified by the authors, was arbitrary assumed to be 5 .

\subsection{Modeling the porewater profiles of $\mathrm{Hg}_{\mathrm{T}}$ and $\mathrm{MeHg}$ in Lake Tantaré}

The porewater $\mathrm{Hg}_{\mathrm{T}}$ or MeHg profiles result from transport processes and reactions that release $\mathrm{Hg}_{\mathrm{T}}$ or $\mathrm{MeHg}$ to or remove them from the aqueous phase. Assuming steady-state and neglecting 
252 advective fluxes due to sediment burial, compaction or groundwater flow (Gallon et al., 2004), the

253 distribution of porewater $\mathrm{Hg}_{\mathrm{T}}$ can be described by the following one-dimensional mass balance

254 equation (Boudreau, 1997):

255

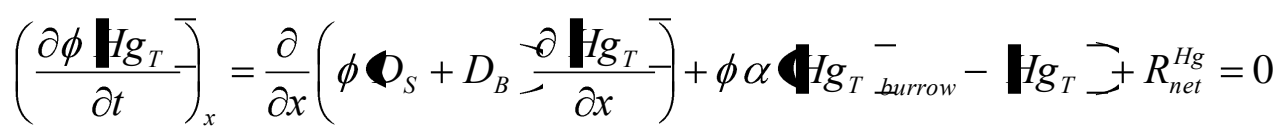

where $x$ represents depth (cm; positive downward), $t$ is time (s), $\phi$ is sediment porosity, $D_{S}$ is the effective diffusion coefficient of $\mathrm{Hg}$ species in sediments $\left(\mathrm{cm}^{2} \mathrm{~s}^{-1}\right), D_{B}$ is the biodiffusion coefficient $\left(\mathrm{cm}^{2} \mathrm{~s}^{-1}\right), \alpha$ is the bioirrigation coefficient $\left(\mathrm{s}^{-1}\right), \quad \mathrm{Hg}_{T}{ }_{\text {burrow }}^{-}$is $\mathrm{Hg}_{\mathrm{T}}$ concentration in the burrows of benthic animals ( $\mathrm{mol} \mathrm{cm} \mathrm{cm}^{-3}$ of porewater), which is assumed to be identical to that in the water overlying the sediments, and $R_{n e t}^{H g}$ is the net reaction rate $\left(\mathrm{mol} \mathrm{cm}{ }^{-3}\right.$ of whole sediment s${ }^{-1}$ ) of

$\mathrm{Hg}_{\mathrm{T}}$ released to $\left(R_{\text {net }}^{\mathrm{Hg}}>0\right)$ or consumed from $\left(R_{\text {net }}^{\mathrm{Hg}}<0\right)$ the aqueous phase. A similar equation can be written for the distribution of dissolved $\mathrm{MeHg}$, where $\mathrm{Hg}_{\mathrm{T}}$ is replaced by $\mathrm{MeHg}$ in Eq. (1); the term $R_{n e t}^{\mathrm{MeHg}}$ then represents the net rate of $\mathrm{MeHg}$ production to or removal from porewater.

We assumed that $D_{S}=\phi^{2} D_{W}$ (Berner, 1980) where $D_{W}$ is the tracer diffusion coefficient of the major $\mathrm{Hg}$ (or $\mathrm{MeHg}$ ) species present in porewater. Considering that major dissolved $\mathrm{Hg}_{\mathrm{T}}$ species are complexes with sulfide and polysulfides in porewaters of both Basins A and B (see section 3.1), we adopted a $D_{W}$ value of $9.5 \times 10^{-6} \mathrm{~cm}^{-2} \mathrm{~s}^{-1}$ at $25^{\circ} \mathrm{C}$, as proposed by Gill et al. (1999) for inorganic $\mathrm{Hg}$ complexes. With regard to $\mathrm{MeHg}$, we used the $D_{W}$ value provided by 270 Hammerschmidt and Fitzgerald (2004) for MeHgSH $\left(1.2 \times 10^{-5} \mathrm{~cm}^{-2} \mathrm{~s}^{-1}\right.$ at $\left.25^{\circ} \mathrm{C}\right)$, the main species 271 of dissolved $\mathrm{MeHg}$ according to our calculations with WHAM 6. The chosen $D_{W}$ values for $\mathrm{Hg}_{\mathrm{T}}$ 
272 and $\mathrm{MeHg}$ were then corrected for in situ temperature at our sampling sites $\left(4^{\circ} \mathrm{C}\right)$ with the Stokes-

273 Einstein equation (Boudreau, 1997).

274

275

For modeling Basin A porewater $H_{T}$ and $\mathrm{MeHg}$ profiles, the value of biodiffusion

276

coefficient $\left(2.2 \times 10^{-9} \mathrm{~cm}^{2} \mathrm{~s}^{-1}\right)$ provided by Gallon et al. (2004) was used in Eq. (1). This value was

277 determined on the basis of an extensive inventory at the sampling site of the benthic fauna, which

278 comprises mostly chironomids (Hare et al., 1994), and of biodiffusion coefficients for chironomids

279 (Matisoff and Wang, 2000). The bioirrigation coefficient ( $\alpha$ ) for Basin A was assumed to

280 decrease linearly from $\alpha^{0}$ at the sediment surface to zero at $10 \mathrm{~cm}$ depth, because chironomids are 281 generally not found below this sediment depth (Matisoff and Wang, 1998), and $\alpha^{0}$ was derived 282 from the following relationship provided by Boudreau (1984):

$283 \quad \alpha^{0}=\frac{D_{S} r_{1}}{\mathbf{Q}_{2}^{2}-r_{1}^{2}-\mathbf{C}_{a}-r_{1}}$

284 where $r_{1}$ is the radius of a chironomid's tube (assumed to be $0.1 \mathrm{~cm}$ ), $r_{2}$ is half the distance

285 between adjacent tubes $(1.5 \mathrm{~cm})$, and $r_{a}$ is equal to $r_{2} / 2$. Given the seasonal development of

286 anoxia in Basin $\mathrm{B}$, we assumed that the biodiffusion $\left(D_{B}\right)$ and bioirrigation $(\alpha)$ coefficients were 287 negligible for this basin.

288

289

Equation 1 was solved numerically for $R_{\text {net }}^{\mathrm{Hg}}$ or $R_{\text {net }}^{\mathrm{MeHg}}$ using the code PROFILE (Berg et al., 290 1998). PROFILE first determines the minimum number of equally spaced depth intervals (or zones) with uniform values of $R_{n e t}^{H g}$ or $R_{n e t}^{\mathrm{MeHg}}$ needed to fit a measured $H g_{T}$ or $\mathrm{MeHg}$ profile with parabola sections, based on the least-squares criterion. Using statistical F-testing, it then 
293 determines if combining adjacent zones with close values of $R_{n e t}^{\mathrm{Hg}}$ or $R_{n e t}^{\mathrm{MeHg}}$ can be done without

294 reducing the quality of the fit. This procedure allows an objective selection, among all the possible

295 solutions, of the one that gives the simplest $R_{\text {net }}^{\mathrm{Hg}}$ or $R_{\text {net }}^{\mathrm{MeHg}}$ depth functions, which show as

296 piecewise constant functions.

297

298

299

300

301

302

303

304

305

306

307

308

309

310

311

312

313

314

315

\section{RESULTS}

\subsection{Porewater}

The concentrations of dissolved $\mathrm{Hg}_{\mathrm{T}}$ varied between DL and $9 \mathrm{pM}$ in Basin A and between DL and $40 \mathrm{pM}$ in Basin B (Fig. 2a-d). These concentrations are among the lowest values reported for freshwater environments such as Lake St. Pierre (4-20 pM; Goulet et al., 2007), Lakes Philips and St. George (40-100 pM; He et al., 2007) and Lakes Clearwater and McFarlane (10-100 pM with some values up to $200 \mathrm{pM}$; Belzile et al., 2008). Porewater MeHg concentrations varied between DL and $1.3 \mathrm{pM}$ in Basin A and between DL and $10 \mathrm{pM}$ in Basin B (Fig. 2e-h) and represented $<1 \%$ to $20 \%$ of $\left[\mathrm{Hg}_{\mathrm{T}}\right]$ with a few extreme values up to $45 \%$. These concentrations are also among the lowest values reported for porewaters in freshwater environments such as a seepage lake (0.5-8 pM; Hines et al., 2004), Lake St-Pierre ( $<0.05-9$ pM; Goulet et al., 2007) and Lakes Philips and St.

George (5-30 pM; He et al., 2007). The fact that the $\left[\mathrm{Hg}_{\mathrm{T}}\right]$ and $[\mathrm{MeHg}]$ profiles are defined by multiple data points suggests that they are not shaped by sampling and handling artifacts.

In Basin A, the [Fe] profiles (Fig. 2i, j) displayed sharp concentration gradients close to the sediment-water interface due to the intense recycling of Fe-ox (Chappaz et al., 2008). 
316 Furthermore, consistent with the occurrence of oxygenated bottom water, $\left[\mathrm{SO}_{4}{ }^{2-}\right]($ Fig. $2 \mathrm{u}, \mathrm{v})$ was

317 relatively high and $[\Sigma \mathrm{S}(-\mathrm{II})]$ (Fig. $2 \mathrm{~m}-\mathrm{n})$ was below detection limit in the sediment overlying

318 water. Sulfate concentration decreased with depth below the sediment-water interface whereas

$319[\Sigma \mathrm{S}(-\mathrm{II})]$ progressively increased below $2-6 \mathrm{~cm}$ depth in the sediments, depending on the sampling date. The vertical profiles of $\left[\mathrm{Hg}_{\mathrm{T}}\right]$ and $[\mathrm{MeHg}]$, in contrast to those of $[\mathrm{Fe}],\left[\mathrm{SO}_{4}{ }^{2-}\right]$ and

$321[\Sigma \mathrm{S}(-\mathrm{II})]$, which displayed sharp variations, were almost featureless, except for two [MeHg]

322 profiles showing a notable $\mathrm{MeHg}$ increase at 5-10 cm depth in September 2005 and at 1-6 cm

323 depth in September 2006. The lack of correlation between the profiles of $\left[\mathrm{Hg}_{\mathrm{T}}\right]$ and $[\mathrm{MeHg}]$ and

324 those of $[\mathrm{Fe}]$ suggests that they are not coupled in a simple manner. The few trend dissimilarities

325 observed among the profiles of $[\mathrm{MeHg}]$ as well as those of $\left[\mathrm{SO}_{4}{ }^{2-}\right],[\Sigma \mathrm{S}(-\mathrm{II})]$ and $[\Sigma \mathrm{S}(0)](\mathrm{Fig} .2 \mathrm{q}-$

326 r) indicate some sediment lateral heterogeneity at the scale of our porewater sampling area ( 25

$\left.327 \mathrm{~m}^{2}\right)$.

The concentration gradients found for most solutes $\left(\mathrm{Hg}_{\mathrm{T}}, \mathrm{MeHg}, \mathrm{Fe}, \mathrm{SO}_{4}, \Sigma \mathrm{S}(-\mathrm{II})\right)$ above the sediment-water interface in Basin B suggest that a few $\mathrm{cm}$ thick nepheloid layer was present above the sediment surface during both sampling periods and that solutes were transported by diffusion across this layer. Even though some lateral heterogeneity was evident from the profiles of the various solutes, the relatively higher $\left[\mathrm{SO}_{4}{ }^{2-}\right]$ and lower $\Sigma \mathrm{S}(-\mathrm{II})$ in the sediment overlying water in July 2007 (Fig. 2x, p) than in October 2006 (Fig. 2w, o) reflected a shift in bottom water redox conditions. However, the profiles of $[\mathrm{Fe}]$ displayed only subtle differences in vertical trends, if any, among the sampling dates (Fig. 3k-1). All the [Fe] profiles suggest a weak remobilization of

337 Fe in the sediments and a small upward diffusive Fe flux across the sediment-water interface. 
remained quite similar, i.e., $\left[\mathrm{Hg}_{\mathrm{T}}\right]$ and $[\mathrm{MeHg}]$ were higher in the overlying water than in

porewater and progressively decreased downwards to $2-5 \mathrm{~cm}$ depth below the sediment-water

341 interface. As in Basin $\mathrm{A}$, the $\left[\mathrm{Hg}_{\mathrm{T}}\right]$ and $[\mathrm{MeHg}]$ profiles showed no obvious correlation with those

342 of $[\mathrm{Fe}]$. On the contrary to what was observed in Basin A, where sulfate reduction occurred in

343 porewater, the $\left[\mathrm{SO}_{4}{ }^{2-}\right], \Sigma \mathrm{S}(-\mathrm{II})$ and $\Sigma \mathrm{S}(0)$ profiles indicate that sulfate reduction took place above

344 the sediment-water interface in this basin.

Thermodynamic calculations with the code WHAM 6 predict that dissolved $\mathrm{Hg}$ speciation was markedly different in Basins A and B (Fig. 3a-h). Since the measurements of $\mathrm{Hg}$ and $\mathrm{MeHg}$ and those of other physico-chemical parameters could not all be carried out in samples collected from the same peepers, we used average values of all the physico-chemical parameters in calculating $\mathrm{Hg}$ and $\mathrm{MeHg}$ speciation. Given the heterogeneity observed among replicate profiles of some key parameters (e.g., $\sum \mathrm{S}(-\mathrm{II}), \sum \mathrm{S}(0), \mathrm{Hg}_{\mathrm{NM}}, \mathrm{MeHg}$; Fig. $2 \mathrm{a}-\mathrm{h}$ and $\left.\mathrm{m}-\mathrm{t}\right)$, there is some uncertainty in the predicted $\mathrm{Hg}_{\mathrm{NM}}$ and $\mathrm{MeHg}$ speciation shown in Fig. 3a-h. In the overlying water of Basin A, where sulfide and zero-valent $\mathrm{S}$ concentrations were below detection limit, $\mathrm{Hg}_{\mathrm{NM}}$ was predicted to be present mostly as complexes with humic substances (>99\%), and $\mathrm{MeHg}$ as $\mathrm{CH}_{3} \mathrm{HgOH}(\sim 90 \%)$. At porewater $\Sigma \mathrm{S}(-\mathrm{II})$ above detection limit in this basin, however, calculations predicted that most of $\mathrm{Hg}_{\mathrm{NM}}$ was rather in the form of $\mathrm{HgS}_{\mathrm{aq}}$, with only 2-3\% bound to humic substances, and that $\mathrm{MeHg}$ likely existed mainly as $\mathrm{CH}_{3} \mathrm{HgSH}$. As for Basin $\mathrm{B}$, thermodynamic predictions are that most of the $\mathrm{Hg}_{\mathrm{NM}}$ was in the form of polysulfide complexes when $\Sigma \mathrm{S}(0)$ was above $0.2 \mu \mathrm{M}$, and as sulfide complexes when $\Sigma \mathrm{S}(0)$ was below $0.2 \mu \mathrm{M}$. Most of the MeHg was predicted to be in the form of $\mathrm{MeHgS}^{-}(18 \pm 3 \%)$ and $\mathrm{MeHgSH}(80 \pm 3 \%)$. $\mathrm{Hg}_{\mathrm{NM}}$ and $\mathrm{MeHg}$ complexes with humic substances 
362 in Basin B than in Basin A (data not shown). It is noteworthy that similar conclusions about the

363 speciation of $\mathrm{Hg}_{\mathrm{NM}}$ and $\mathrm{MeHg}$ in sediment porewater were reached by Goulet et al. (2007) and

364 Merritt and Amirbahman (2007, 2008).

365

366

\subsection{Solid-phase}

367

368

Solid-phase Fe concentration sharply decreased in the top 2-cm layer of Lake Tantaré Basin

369 A sediments (Fig. 4g) and then remained nearly constant downwards. This near surface Fe

370 enrichment results from the intense redox recycling of Fe in the sediments of this basin (Laforte et

371 al., 2005); it is consistent with the sharp porewater [Fe] gradients close to the sediment-water

372 interface (Fig. 2i, j). If we assume that the concentration of authigenic Fe-ox in the top 0.5-cm

373 sediment layer is the difference between the measured $\{\mathrm{Fe}\}$ concentration in this layer and the

374 constant background $\{\mathrm{Fe}\}$ value below $15 \mathrm{~cm}$ depth, then $\{\mathrm{Fe}-\mathrm{ox}\}=1.55 \times 10^{-3} \mathrm{~mol} \mathrm{~g}^{-1}$ (Table 3 ).

375 Comparable surface sediment Fe enrichment is absent from Basin B and from the other two lakes

376 where the bottom waters become seasonally anoxic (Fig. 4h-j). In Lakes Bédard and Holland

377 sediments, maximum $\{\mathrm{Fe}\}$ were coincidental with AVS peaks that occurred at $3.75-5.25 \mathrm{~cm}$ depth

378 (Fig. 4q, r). Sediment and porewater Mn profiles (Figs. 4g-j and 2i-1) did not show any evidence of

379 redox recycling of this element, consistent with the anoxic condition (Lakes Bédard and Holland

380 and Basin B of Lake Tantaré) or with the slightly acidic condition of porewater (Basin A of Lake

381 Tantaré; Laforte et al., 2005).

382

383

Organic $\mathrm{C}$ concentrations in the sediments of the three study lakes ranged from $\sim 16 \%$ and

$384 \sim 35 \%$; they varied with depth in Lake Holland, but remained nearly monotonic in the other lakes 
385 (Fig. 4 k-n). The average $( \pm \mathrm{SD})\left\{\mathrm{C}_{\text {org }}\right\}:\{\mathrm{N}\}$ molar ratios of the sediments, over the whole cores, were $16.7 \pm 0.7,16.6 \pm 2.2,16.3 \pm 2.3$ and $13.7 \pm 1.2$ for Basins A and B of Lake Tantaré and for Lakes Bédard and Holland, respectively. Such large $\left\{\mathrm{C}_{\mathrm{org}}\right\}:\{\mathrm{N}\}$ ratios are consistent with organic matter being mainly humic substances derived from the watershed rather than autochtonous organic matter (Feyte et al., 2010); indeed, these ratios are much larger than those (6.4 - 6.6) reported for phytoplankton or for settling particles in a productive lake (Redfield, 1934; Hamilton-

391 Taylor et al., 1984), but close to those of soil humic substances (Buffle, 1988). The $\left\{\mathrm{C}_{\text {org }}\right\}:\{\mathrm{N}\}$

392 ratio in the top $0.5-\mathrm{cm}$ sediment layer of Basin A was 15.5, a value very close to that measured 393 (15.3 \pm 3.4$)$ in the Fe-rich diagenetic material collected on Teflon sheets (Table 3). Organic matter 394 in surface sediment and that associated to the diagenetic material can thus be assumed to have the 395 same origin. The slightly lower $\left\{\mathrm{C}_{\text {org }}\right\}:\{\mathrm{N}\}$ molar ratios in surface sediments and in the diagenetic 396 material than the average $( \pm \mathrm{SD})$ ratio for the whole core $(16.7 \pm 0.7)$ are consistent with the 397 presence of small amounts of autochtonous labile organic matter present at the sediment surface. 398 Notably, the $\left\{\mathrm{C}_{\mathrm{org}}\right\}:\{\mathrm{Fe}\}$ molar ratio of $2.6 \pm 0.3$ (Table 3 ) found in the Fe-rich material indicates 399 that it contains substantial amounts of organic matter. The $\left\{\mathrm{C}_{\mathrm{org}}\right\}:\{\mathrm{Fe}\}$ molar ratio of the 400 diagenetic material is, however, much smaller than that measured in the top 0.5-cm layer of 401 sediments (13; Table 3), thus indicating that most of humic substances in the sediments was not 402 bound to Fe-ox but was present as organic coating on other solids or as separate particles. 403 At each of the sampling sites where AVS was measured, maximum concentrations occurred 405 at depths ranging from 3.25 to $8.75 \mathrm{~cm}$ (Fig. 4o, q, r). The $\left\{\mathrm{S}_{\mathrm{T}}\right\}$ and $\{$ AVS $\}$ profiles exhibited 406 subsurface maxima at the same depth in Lakes Bédard and Holland sediments, but not in those of 407 Lake Tantaré Basin A where the $\mathrm{S}_{\mathrm{T}}$ peak was slightly deeper than the AVS peak. An important 
aspect of these results is that AVS represents only a minor fraction of $\left\{S_{\mathrm{T}}\right\}$ in Lakes Tantaré and Bédard sediments and a small fraction in Lake Holland sediments. For instance, the inventories of AVS over the total length of the cores are equivalent to $0.5 \%, 3 \%$ and $26 \%$ of those of $\mathrm{S}_{\mathrm{T}}$ for

411 Lakes Tantaré (Basin A), Bédard and Holland, respectively. Using a non-steady state one-

412 dimensional reactive transport modeling approach, Couture et al. (2010b) concluded that the AVS

413 concentrations in Basin A sediments are about one order of magnitude lower than what they should

414 be considering the sulfate reduction rate. If, as their model indicates, pyrite does not form in these

415 sediments due to slow kinetics and low porewater $\sum \mathrm{S}(-\mathrm{II})$, the high rate of $\mathrm{SO}_{4}$ reduction and the

416 low AVS inventory could then only be reconciled by inferring that most of the sulfide produced

417 became associated to the organic matter. Substantial laboratory and field evidences exist for the 418 incorporation of dissolved sulfide to humic substances (e.g., Canfield et al., 1998; Einsield et al., 419 2008).

The concentrations of $\mathrm{Hg}_{\mathrm{T}}$ measured in the sediments of the three study lakes ranged

422 between 0.6 and $3.0 \mathrm{nmol} \mathrm{g}^{-1}$ (Fig. 4a-d). These values are typical of those reported for other lake 423 sediments from North-Eastern United States to Northern Canada and Alaska (e.g. Perry et al., 2005; Fitzgerald et al., 2005; Engstrom et al., 2007; Mills et al., 2009; Muir et al., 2009). While the ranges for $\left\{\mathrm{Hg}_{\mathrm{T}}\right\}$ in Lake Tantaré Basins $\mathrm{A}$ and $\mathrm{B}$ were similar, their profiles exhibited striking differences (Fig. 4a, b). In Basin $\mathrm{A},\left\{\mathrm{Hg}_{\mathrm{T}}\right\}$ increased progressively toward the sediment surface 427 from an average ( \pm SD) background value of $1.07 \pm 0.08 \mathrm{nmol} \mathrm{g}-1$ below $15 \mathrm{~cm}$ to an uppermost 428 value of $3.0 \mathrm{nmol} \mathrm{g}^{-1}$ at the sediment surface. The $\left\{\mathrm{Hg}_{\mathrm{T}}\right\}:\{\mathrm{Fe}\}$ molar ratio in the Fe-rich material $429\left(1.3 \pm 0.3 \times 10^{-7}\right)$ was much lower than in the top 0.5 -cm sediment layer $\left(1.9 \times 10^{-6}\right)($ Table 3$)$. In 430 Basin $\mathrm{B},\left\{\mathrm{Hg}_{\mathrm{T}}\right\}$ increased from a background value of $0.91 \pm 0.06 \mathrm{nmol} \mathrm{g}^{-1}$ at the bottom of the 
431 core to a sub-surface maximum of $2.8 \mathrm{nmol} \mathrm{g}^{-1}$ at a depth of $5.25 \mathrm{~cm}$ and then decreased

432 progressively to $2.3 \mathrm{nmol} \mathrm{g}^{-1}$ at the sediment surface. The average $( \pm \mathrm{SD})$ partition coefficient for $433 \mathrm{Hg}_{\mathrm{T}}\left(\mathrm{K}_{\mathrm{D}}^{\mathrm{Hg}}=\left\{\mathrm{Hg}_{\mathrm{T}}\right\} /\left[\mathrm{Hg}_{\mathrm{T}}\right]\right)$ in sediments of Basins $\mathrm{A}$ and $\mathrm{B}\left(\log \mathrm{K}_{\mathrm{D}}^{\mathrm{Hg}}=5.7 \pm 0.2\right)$ is slightly higher 434 than those reported for other freshwater sediments $\left(\log \mathrm{K}_{\mathrm{D}}^{\mathrm{Hg}}=3.7-4.5\right.$; He et al., 2007; Goulet et 435 al, 2007; Belzile et al., 2008). It is noteworthy that the profiles of the $\left\{\mathrm{Hg}_{\mathrm{T}}\right\}:\{\mathrm{Al}\}$ molar ratio and 436 those of $\left\{\mathrm{Hg}_{\mathrm{T}}\right\}$ exhibited very similar trends in the two basins of Lake Tantaré and of Lake

437 Bédard, but not in Lake Holland (Fig. 4a-d). The $\left\{\mathrm{Hg}_{\mathrm{T}}\right\}:\{\mathrm{Al}\}$ ratio varied between $7.2 \pm 0.7 \times 10^{-7}$ 438 and $22 \times 10^{-7}\left(\right.$ Basin A) or $29 \times 10^{-7}$ (Basin B) in Lake Tantaré sediments and between $7.1 \pm 0.4 \times$ $43910^{-7}$ and $11.8 \times 10^{-7}$ in those of Lake Bédard. In Lake Holland, the $\left\{\mathrm{Hg}_{\mathrm{T}}\right\}:\{\mathrm{Al}\}$ ratio varied steeply 440 with depth; it decreased from the sediment-water interface $\left(17 \times 10^{-7}\right)$ to $13 \mathrm{~cm}$ depth $\left(5.6 \times 10^{-7}\right)$, 441 increased sharply below this horizon to reach a maximum at $21 \mathrm{~cm}$ depth $\left(34 \times 10^{-7}\right)$ and then 442 decreased to $20 \times 10^{-7}$ at the bottom of the core. Note that all the $\left\{\mathrm{Hg}_{\mathrm{T}}\right\}:\{\mathrm{Al}\}$ values, even the 443 preindustrial ones at the bottom of the cores, are higher than the average $\left\{\mathrm{Hg}_{\mathrm{T}}\right\}:\{\mathrm{Al}\}$ molar ratio in 444 the Upper Continental Crust $\left(0.7 \times 10^{-7}\right.$; Wedepohl, 1995) suggesting that even the preindustrial $445\left\{\mathrm{Hg}_{\mathrm{T}}\right\}$ does not comprise only lithogenic $\mathrm{Hg}$.

The concentrations of sediment MeHg in Basins A and B of Lake Tantaré varied from 3 to 75 $448 \mathrm{pmol} \mathrm{g}{ }^{-1}$, representing 0.2 to $2.5 \%$ of $\left\{\mathrm{Hg}_{\mathrm{T}}\right\}$ and are typical of those reported for other lake 449 sediments of the North American continent (e.g. Ethier et al., 2010; He et al., 2007; Hines et al., 450 2004). The solid-phase distribution of MeHg in Basin A contrasts with that in Basin B. Surface 451 sediments are enriched in $\{\mathrm{MeHg}\}$ in Basin $\mathrm{A}$, but not in Basin B. Surface sediment enrichments 452 in $\mathrm{MeHg}$ were also observed in other lake sediments and were attributed to MeHg production 453 and/or deposition at the sediment surface and subsequent demethylation with sediment burial 
454 (Hines et al., 2004; He et al., 2007; Rydberg et al., 2008). In the Fe-rich deposits collected with the

455 Teflon sheets in Basin A, the average $(\mathrm{n}=7)\{\mathrm{MeHg}\}:\{\mathrm{Fe}\}$ molar ratio was $6.5 \pm 1.9 \times 10^{-10}$, a

456 much lower value than that found in the top $0.5-\mathrm{cm}$ sediment layer $\left(4.9 \times 10^{-8}\right.$; Table 3$)$. The

457 average $( \pm \mathrm{SD})$ partition coefficient for $\mathrm{MeHg}\left(\mathrm{K}_{\mathrm{D}}{ }^{\mathrm{MeHg}}=\{\mathrm{MeHg}\} /[\mathrm{MeHg}]\right)$ in Basin A and B

458 sediments $\left(\log \mathrm{K}_{\mathrm{D}}^{\mathrm{MeHg}}=4.7 \pm 0.4\right)$ was slightly higher than those reported for other lake

459 sediments $\left(\log \mathrm{K}_{\mathrm{D}}^{\mathrm{MeHg}}=0.5-4\right.$; He et al., 2007; Goulet et al., 2007).

460

461

4. DISCUSSION

462

463

\subsection{Modeling the $\left[\mathrm{Hg}_{\mathrm{T}}\right]$ profiles}

464

465

The modeled $\left[\mathrm{Hg}_{\mathrm{T}}\right]$ profiles for the average $(\mathrm{n}=3)$ porewater $\mathrm{Hg}_{\mathrm{T}}$ distribution in each basin of

466 Lake Tantaré and sampling date as well as the zones of $\mathrm{Hg}_{\mathrm{T}}$ production or consumption are shown

467 in Fig. 3i-l whereas the values of the net rate $\left(R_{n e t}^{H g}\right)$ in each zone, numbered downward from the

468 sediment-water interface, are given in Table 4. For calculating the average $\left[\mathrm{Hg}_{\mathrm{T}}\right]$, we assumed a

469 value of $0.5 \mathrm{DL}$ for all undetected concentrations. In Basin A, the modeled $\left[\mathrm{Hg}_{\mathrm{T}}\right]$ profiles were in

470 relatively good agreement $\left(r^{2}=0.76-0.82\right)$ with the measured profiles. In September 2005 , there

471 was a 6-cm thick zone of slow net $\mathrm{Hg}$ consumption $\left(R_{n e t}^{\mathrm{Hg}}=-0.7 \times 10^{-21} \mathrm{~mol} \mathrm{~cm} \mathrm{cs}^{-1}\right)$ just below the

472 sediment-water interface, above a zone of slow net $\mathrm{Hg}_{\mathrm{T}}$ production $\left(R_{\text {net }}^{H g}=2.4 \times 10^{-21} \mathrm{~mol} \mathrm{~cm}^{-3} \mathrm{~s}^{-}\right.$

$473^{1}$ ). In September 2006, PROFILE suggests the occurrence of a single zone of slow net $\mathrm{Hg}_{\mathrm{T}}$

474 consumption $\left(R_{n e t}^{H g}=-0.8 \times 10^{-21} \mathrm{~mol} \mathrm{~cm}^{-3} \mathrm{~s}^{-1}\right)$ between the sediment-water interface and $10 \mathrm{~cm}$

475 depth. In Basin B, the $R_{n e t}^{H g}$ values provided by PROFILE were larger than those found in Basin A 
476 and the modelled and measured $\left[\mathrm{Hg}_{\mathrm{T}}\right]$ profiles were in better agreement $\left(\mathrm{r}^{2}=0.95-0.96\right)$. At both

477 sampling periods, there was consistently a 4-6-cm thick zone of relatively fast net consumption of

478 dissolved $\operatorname{Hg}_{\mathrm{T}}\left(R_{\text {net }}^{\mathrm{Hg}}=-3.6 \times 10^{-21} \mathrm{~mol} \mathrm{~cm} \mathrm{~cm}^{-3}\right.$ to $\left.-14 \times 10^{-21} \mathrm{~mol} \mathrm{~cm}^{-3} \mathrm{~s}^{-1}\right)$ above a zone of

479 relatively fast net $\mathrm{Hg}_{\mathrm{T}}$ production $\left(R_{\text {net }}^{H g}=1.7 \times 10^{-21} \mathrm{~mol} \mathrm{~cm}^{-3} \mathrm{~s}^{-1}\right.$ to $\left.11 \times 10^{-21} \mathrm{~mol} \mathrm{~cm}^{-3} \mathrm{~s}^{-1}\right)$. Note

480 that the $R_{n e t}^{\mathrm{Hg}}$ values for the release of $\mathrm{Hg}_{\mathrm{T}}$ to Lake Tantaré porewater were 3-15 times lower than

481 those reported by Merritt and Amirbahman (2007) for the highly contaminated Penobscot River-

482 Estuary sediments $\left(R_{\text {net }}^{H g}=37 \times 10^{-21} \mathrm{~mol} \mathrm{~cm}^{-3} \mathrm{~s}^{-1}\right.$ to $\left.52 \times 10^{-21} \mathrm{~mol} \mathrm{~cm}^{-3} \mathrm{~s}^{-1}\right)$. As for the net rates of

$483 \mathrm{Hg}_{\mathrm{T}}$ removal from porewater, they were of similar magnitude to those of the Penobscot River-

484 Estuary $\left(R_{\text {net }}^{H g}=-7.5 \times 10^{-21} \mathrm{~mol} \mathrm{~cm}^{-3} \mathrm{~s}^{-1}\right.$ to $\left.-14 \times 10^{-21} \mathrm{~mol} \mathrm{~cm}^{-3} \mathrm{~s}^{-1}\right)$ only in Basin B sediments.

485

486

Thus, Fig. 3i-l indicates consistently that $\mathrm{Hg}_{\mathrm{T}}$ is removed in zone 1, located just below the 487 sediment-water interface; thickness of the zone $(4-10 \mathrm{~cm})$ and intensity of net $\mathrm{Hg}_{\mathrm{T}}$ removal vary 488 with sampling site and date, and net removal rate is faster in Basin B than in Basin A.

Mechanisms that control porewater $\mathrm{Hg}_{\mathrm{T}}$ concentrations might include precipitation/dissolution of 490 minerals such as cinnabar $\left(\mathrm{HgS}_{(\mathrm{s})}\right)$ and montroydite $\left(\mathrm{HgO}_{(\mathrm{s})}\right)$ (e.g., Winfrey and Rudd, 1990; Ullrich et al., 2001), Hg adsorption to Fe and Mn oxyhydroxides (e.g., Gobeil and Cossa, 1993; Gagnon et al., 1997; Bloom et al., 1999; Hammerschmidt et al., 2004; Heyes et al., 2004; Turner et al., 2004), Hg adsorption to or coprecipitation with Fe sulfide (e.g., Morse and Luther, 1999; Merritt and Amirbahman, 2007; Jeong et al., 2007; Liu et al., 2008) and Hg reaction with organic matter (e.g., Hammerschmidt and Fitzgerald, 2004; Sunderland et al., 2006; Hollweg et al., 2009). 
Precipitation of cinnabar $\left(\mathrm{HgS}_{(\mathrm{s}, \text { cinnabar })}\right.$; reaction 23 in Table 2$)$ is not responsible for the observed net porewater $\mathrm{Hg}_{\mathrm{T}}$ removal in Lake Tantaré sediments. This is supported by comparison of the ion activity product (IAP) and the solubility product $\left(\mathrm{K}_{\mathrm{s}}\right)$, which indicates that, in both basins and at all sampling periods, the porewater, from the sediment-water interface to $10 \mathrm{~cm}$ depth, was always undersaturated by more than two orders of magnitude with respect to cinnabar. A similar conclusion can be made for the precipitation of montroydite $\left(\mathrm{HgO}_{(\mathrm{s})}\right)$, reaction 24 in Table 2) with porewater being undersaturated by more than 25 orders of magnitude with respect to this solid. It should be noted that varying the value of "y" between 2 and 7 for the complexes $\mathrm{HgS}_{\mathrm{y}} \mathrm{OH}^{-}$and $\mathrm{Hg}\left(\mathrm{S}_{\mathrm{y}}\right)_{2}{ }^{2-}$ does not alter our conclusion on the saturation state of porewater with respect to these solids. Goulet et al. (2007) also reported that the porewater of a riverine wetland was undersaturated with respect to these solids.

\section{The presence of $\mathrm{Hg}$ in the Fe-rich authigenic material collected on Teflon sheets (Table 3)} indicates that some $\mathrm{Hg}$ is removed from Basin A porewater by authigenic Fe-ox or its associated organic matter. By multiplying the $\left\{\mathrm{Hg}_{\mathrm{T}}\right\}:\{\mathrm{Fe}\}$ molar ratio measured in the Fe-rich material collected with Teflon sheets by the concentration of authigenic Fe-ox in the top 0.5 -cm sediment layer (Table 3), we estimate that, at the most, $1.9 \times 10^{-10} \mathrm{~mol} \mathrm{~g}^{-1}$, i.e., $\sim 6 \%$ of $\left\{\mathrm{Hg}_{\mathrm{T}}\right\}\left(3 \times 10^{-9} \mathrm{~mol}\right.$ $\mathrm{g}^{-1}$ ), would be bound to the Fe-ox or to its associated organic matter in this sediment layer. An implicit assumption in that calculation is that the authigenic Fe-ox in the top 0.5-cm layer of the sediment have a similar composition to those collected on the Teflon sheets. In Basin A of Lake Tantaré, strong correlations have been observed between porewater [As] (Couture et al., 2010a) or [Mo] (Chappaz et al., 2008) and [Fe] profiles because these anionic trace elements show a strong coupling with Fe redox recycling and they are not readsorbed quickly when they are released by 
520 dissolution of the Fe-ox. The lack of correlation between the porewater $\left[\mathrm{Hg}_{\mathrm{T}}\right]$ and $[\mathrm{Fe}]$ profiles

521 (Fig. 2 a, b and i, j) could be explained by a weaker involvement of $\mathrm{Hg}$ in the Fe redox recycling

522 and/or a fast readsorption of the $\mathrm{Hg}$ released following the reductive dissolution of the Fe-ox.

523 Adsorption of $\mathrm{Hg}$ onto Fe-ox in Basin B sediments can be ruled out since authigenic Fe-ox are

524 absent or at low concentrations in the sediments of this Basin, due to the seasonally anoxic

525 condition (see Figs $2 \mathrm{k}, \mathrm{l}$ and $4 \mathrm{~h}$ ). Likewise, removal of porewater $\mathrm{Hg}_{\mathrm{T}}$ by adsorption onto $\mathrm{Mn}$

526 oxyhydroxides can be ignored because the slightly acidic condition of the lake prevents the

527 formation of this authigenic phase (Laforte et al., 2005). Thus, adsorption to Fe-ox or its associated

528 organic matter likely occurs in Basin A sediments but is of minor importance and does not alone

529 explain the differences observed between Basins A and B in the distribution of $\left\{\mathrm{Hg}_{\mathrm{T}}\right\}$ in the top 5

$530 \mathrm{~cm}$ of the sediments (Fig. 4a-b).

531

532 Coincidence in space between the zone of $\mathrm{Hg}_{\mathrm{T}}$ removal in Basin B (Fig. 3k, l) and the depth

533 interval where porewater was slightly oversaturated with respect to disordered mackinawite $\left(\mathrm{FeS} \mathrm{S}_{(\mathrm{s},}\right.$

$534 \mathrm{~m}$ ) ; equation 37 in Table 2) (see Fig. 3s, t) suggests that the relatively fast removal of $\mathrm{Hg}_{\mathrm{T}}$ from

535 porewater in this basin could be explained by its adsorption to or coprecipitation with $\mathrm{FeS}_{(\mathrm{s}, \mathrm{m})}$.

536 This interpretation would also be consistent with the net $\mathrm{Hg}_{\mathrm{T}}$ production in July 2007 in Basin B

537 (Fig. 31) which corresponds to a depth interval $(6-10 \mathrm{~cm})$ where porewater was undersaturated with 538 respect to $\mathrm{FeS}_{(\mathrm{s}, \mathrm{m})}$ (Fig. 3t). However, this mechanism would explain neither the net porewater $\mathrm{Hg}_{\mathrm{T}}$

539 removal in Basin A (zone 1 in Fig. 3i, j), given that porewater was undersaturated with respect to

$540 \mathrm{FeS}_{(\mathrm{s}, \mathrm{m})}\left(\mathrm{Fig} .3 \mathrm{q}, \mathrm{r}\right.$ ), nor the porewater $\mathrm{Hg}_{\mathrm{T}}$ production in Basin B in October 2006 (zone 2; 4-9 cm

541 depth), given that porewater was slightly supersaturated with respect to $\mathrm{FeS}_{(\mathrm{s}, \mathrm{m})}$. However, in all 
542 these latter cases, where very low $\left[\mathrm{Hg}_{\mathrm{T}}\right]$ were modeled, the $R_{\text {net }}^{\mathrm{Hg}}$ values were small and, arguably,

543 could be modeling artifacts.

544

545

546

matter cannot be dismissed, especially in Basin B. Indeed, our data indicate that relatively high

547 concentrations of sulfur are present (Fig. 4p) over the depth interval where $\mathrm{Hg}_{\mathrm{T}}$ is removed from

548 porewater, and, as previously stated in section 3.2, most of the S could be organically-bound.

549 Several studies have speculated that sulfur groups in sediment humic substances could bind $\mathrm{Hg}$

550 (Ravichandran, 2004; Skyllberg, 2008), and such binding has been shown by spectroscopic

551 techniques (XANES) to occur at reduced sulfur sites present in soil humic substances (Xia et al.,

552 1999). There is growing evidence that humic substances become sulfidized in anoxic sediments

553 (e.g., Canfield et al., 1998; Einsield et al., 2008). Also, several studies in coastal marine sediments

554 (e.g., Bloom et al., 1999; Hammerschmidt and Fitzgerald, 2004 and 2006a; Sunderland et al.,

555 2006; Hollweg et al., 2009) have shown a significant correlation between $\log \mathrm{K}_{\mathrm{D}}^{\mathrm{Hg}}$ and $\left\{\mathrm{C}_{\text {org }}\right\}$ or

556 between $\left\{\mathrm{Hg}_{\mathrm{T}}\right\}$ and $\left\{\mathrm{C}_{\mathrm{org}}\right\}$, which were taken as an indication that $\mathrm{Hg}$ was bound to organic

557 matter. We did not observe such correlations, perhaps due to the small depth variation in $\left\{\mathrm{C}_{\text {org }}\right\}$ in

558 the two basins.

559

560 Thus, it can be concluded that pure $\mathrm{Hg}$ mineral phases do not form in Lake Tantaré sediments

561 and that $\mathrm{Hg}_{\mathrm{T}}$ adsorption onto Fe-ox occurs to a limited extent. Moreover, our data do not allow us

562 to demonstrate unambiguously whether $\mathrm{Hg}_{\mathrm{T}}$ associations with Fe sulfide phases or sulfidized

563 organic matter are important processes controlling porewater $\mathrm{Hg}_{\mathrm{T}}$ concentrations in the lacustrine 
564 anoxic sediments. Additional field and laboratory work are clearly needed to better identify the

565 reactions involving $\mathrm{Hg}_{\mathrm{T}}$ in the sediments.

566

567

\subsection{Modeling the $[\mathrm{MeHg}]$ profiles}

568

569

Fitting of the average $(n=3)$ porewater $[\mathrm{MeHg}]$ profiles in each basin and sampling date and

570 the zones of $[\mathrm{MeHg}]$ production or consumption are displayed in Fig. 3m-p whilst the values of the net reaction rates $\left(R_{n e t}^{\mathrm{MeHg}}\right)$ are given in Table 5 for each zone numbered downward from the sediment-water interface. In calculating the average $[\mathrm{MeHg}]$, undetectable concentrations were assumed to be half the DL.

574

575

576

577

578

579

580

581

582

583

584

585
In Basin A, the code PROFILE defined for September 2005 (Fig. 3m) a zone of slow net $\mathrm{MeHg}$ consumption (zone 1) in the first $5 \mathrm{~cm}$ below the sediment-water interface $\left(R_{n e t}^{\mathrm{MeHg}}=-0.2 \times\right.$ $10^{-21} \mathrm{~mol} \mathrm{~cm}^{-3} \mathrm{~s}^{-1}$ ) above a zone of about the same thickness where MeHg was slowly produced (zone 2; $R_{\text {net }}^{\mathrm{MeHg}}=0.3 \times 10^{-21} \mathrm{~mol} \mathrm{~cm}^{-3} \mathrm{~s}^{-1}$ ). For September 2006, PROFILE suggests a different pattern with two zones of net MeHg consumption and of net production (Fig. 3n). However, fitting of the average [MeHg] profile for September 2006 should be taken with caution, due to the high standard deviation on the average $[\mathrm{MeHg}]$ values, especially between the sediment-water interface and $5 \mathrm{~cm}$ depth, thus reflecting some local heterogeneity. When they are modeled individually, two of the $[\mathrm{MeHg}]$ profiles (Fig. 5a and c) yield a $R_{n e t}^{\mathrm{MeHg}}$-depth pattern consistent with that obtained for the average [MeHg] profile of September 2005 (Fig. 3m). However, the other [MeHg] profile (Fig. 5b) shows a zone of fast net MeHg production $\left(R_{\text {net }}^{\mathrm{MeHg}}=5.2 \times 10^{-21} \mathrm{~mol} \mathrm{~cm}^{-3} \mathrm{~s}^{-1}\right)$ located between 
two consumption zones extending, one from the sediment-water interface to $1.5 \mathrm{~cm}$ depth

587

588 sediments $\left(R_{n e t}^{\mathrm{MeHg}}=-10 \times 10^{-21} \mathrm{~mol} \mathrm{~cm}^{-3} \mathrm{~s}^{-1}\right.$ to $\left.-650 \times 10^{-21} \mathrm{~mol} \mathrm{~cm} \mathrm{~cm}^{-3} \mathrm{~s}^{-1}\right)$.

Modeling the average $(n=3)[\mathrm{MeHg}]$ profiles determined in October 2006 and July 2007 in Basin B leads to similar results for the two sampling periods, with an excellent agreement $\left(\mathrm{r}^{2}=\right.$ 0.96-0.99) between measured and modeled data (Fig. 3o, p). It shows a 1.5 to 3 -cm thick zone where MeHg is consumed relatively fast (zone $1 ; R_{n e t}^{M e H g}=-0.9 \times 10^{-21} \mathrm{~mol} \mathrm{~cm}^{-3} \mathrm{~s}^{-1}$ to $-3.5 \times 10^{-21}$ mol cm $\mathrm{cm}^{-3}$ ) above a zone of much slower net MeHg consumption (zone $2 ; R_{n e t}^{M e H g}=-0.01 \times 10^{-21}$ mol cm $\mathrm{cm}^{-1}$ to $-0.03 \times 10^{-21} \mathrm{~mol} \mathrm{~cm}^{-3} \mathrm{~s}^{-1}$ ). The $R_{\text {net }}^{\text {MeHg }}$ values for net MeHg removal from Lake Tantaré porewater are slightly lower than those reported by Goulet et al. (2007) in Lake St. Pierre $\left(R_{\text {net }}^{\mathrm{MeHg}}=-0.1 \times 10^{-21} \mathrm{~mol} \mathrm{~cm} \mathrm{~cm}^{-3} \mathrm{~s}^{-1}\right.$ to $\left.-12.4 \times 10^{-21} \mathrm{~mol} \mathrm{~cm}^{-3} \mathrm{~s}^{-1}\right)$ and much lower than those reported by Merritt and Amirbahman (2008) for the highly contaminated Penobscot River-Estuary 606 
Processes already hypothesized to remove $\mathrm{MeHg}$ from porewater include sorption onto $\mathrm{Fe}-\mathrm{ox}$

608

609 Compeau and Bartha, 1985; Gilmour et al., 1992; King et al., 2001).

614

615
(Bloom et al., 1999; Heyes et al., 2004; Hammerschmidt et al., 2004) and Fe sulfides (Miller, 2006), interaction with organic matter (e.g., Hammerschmidt and Fitzgerald, 2004; Lambertsson and Nilsson, 2006), and microbially-mediated demethylation reactions (e.g., Oremland et al. 1991;

Marvin-Di Pasquale et al., 2000; Benoit et al., 2003). Processes that release MeHg to porewater would be desorption from the solid phases and Hg methylation (e.g., Olson and Cooper, 1974; 
630 decadal time shown in their Fig. 7 and their average sediment accumulation rate value of $0.013 \mathrm{~g}$

$631 \mathrm{~cm}^{-2} \mathrm{yr}^{-1}$, a demethylation rate constant of $4 \times 10^{-5} \mathrm{~d}^{-1}$ can be calculated. Rydberg et al. (2008) also

632 reported a decline in $\{\mathrm{MeHg}\}$ with sediment age in the varved sediments of lake Nylandssjön;

633 using the data shown in their Fig. 3a, we calculate a demethylation rate constant of $6 \times 10^{-5} \mathrm{~d}^{-1}$. It

634 is noteworthy that the rate constant values obtained from the data reported for the seepage lake and

635 Lake Nylandssjön are reasonably similar to that obtained for Basin A. Thus, based on the above

636 considerations, adsorption onto authigenic material and/or demethylation should contribute to the

637 net MeHg consumption observed just below the sediment-water interface in Basin A (zone 1 in

638 Fig. $3 \mathrm{~m}$ and 5a-c).

639

640 In Basin B, the net MeHg removal from porewater (zone 1 in Fig. 3o, p) cannot be ascribed to

641 adsorption onto Fe-ox because there is no evidence for the formation of these oxyhydroxides in

642 this anoxic basin. The MeHg removal zone is however located within the depth interval where

643 porewater was slightly supersaturated with respect to $\mathrm{FeS}_{(\mathrm{s}, \mathrm{m})}(\mathrm{Fig} .3 \mathrm{~s}, \mathrm{t}$ ), suggesting that $\mathrm{MeHg}$

644 could be adsorbed onto or coprecipitated with iron sulfide. This mechanism would explain the

645 slow production of $\mathrm{MeHg}$ between 5 and $10 \mathrm{~cm}$ depth in Basin A sediments (Fig. 3m and 5a, c)

646 where porewater were undersaturated with respect to $\mathrm{FeS}_{(\mathrm{s}, \mathrm{m})}$. However, it would not explain, for

647 example, the slow net MeHg consumption between 3 and $10 \mathrm{~cm}$ depth observed in Basins A (Fig.

$6485 b$ ) and B (Fig. 3p) sediments, which, given the small $R_{n e t}^{M e H g}$ values, might result from modeling

649 artifacts. Lastly, as previously suggested for $\mathrm{Hg}_{\mathrm{T}}$, and as discussed in other studies (Hintelmann et

650 al., 1997; Karlsson and Skyllberg, 2003), removal of MeHg due to interaction with reduced sulfur

651 functional groups on organic matter cannot be dismissed in Basin B sediments, since a large part of 652 the $S_{\mathrm{T}}$ could be organically-bound. 
The zones of net MeHg production in Basin A porewater (Figs. $3 \mathrm{~m}$ and 5a-c) always occur at depth intervals where $\mathrm{SO}_{4}$ is consumed (Fig. $2 \mathrm{u}-\mathrm{v}$ ), thus indicating that methylation by sulfate-

656 reducing bacteria is the likely mechanism of production. Consistent with this mechanism, we do not observe any important $\mathrm{MeHg}$ production in Basin B porewater where there is no $\mathrm{SO}_{4}$ consumption (Fig. 2w-x). In the latter basin, MeHg production occurs in the water column, i.e., where $\mathrm{SO}_{4}$ reduction occurs (Fig. 2w-x), and then MeHg diffuses across the sediment-water interface. Eckley et al. (2005) have shown that MeHg is formed and accumulates in anoxic hypolimnetic lake waters. Laboratory experiments with pure cultures or with $\mathrm{Hg}$-spiked sediments have shown repeatedly the involvement of sulfate reducing bacteria in $\mathrm{Hg}$ methylation (e.g. Olson and Cooper, 1974; Compeau and Bartha, 1985; Gilmour et al., 1992; Benoit et al., 2003). MeHg desorption or its release by dissolution of solid phases to which it was bound could also contribute to the net $\mathrm{MeHg}$ production, but we have no evidence that these mechanisms are important in Lake Tantaré sediments.

$$
R_{n e t}^{\mathrm{MeHg}}=R_{\text {ads }}^{\mathrm{MeHg}}+R_{\text {demethyl }}^{\mathrm{MeHg}}+R_{\text {methyl }}^{\mathrm{Hg}}
$$

671

672 where $R_{a d s}^{\mathrm{MeHg}}$ represents the rate of $\mathrm{MeHg}$ removal from porewater by adsorption onto Fe-ox, Fe sulfide or organic matter, whereas $R_{\text {demethyl }}^{\mathrm{MeHg}}$ and $R_{\text {methyl }}^{\mathrm{Hg}}$ are the rates of $\mathrm{MeHg}$ demethylation and $\mathrm{Hg}$ methylation, respectively. Estimations of field-derived methylation and demethylation rate 675 constants can be obtained when simplifying assumptions are made. 
676 If we assume, for the net consumption zone of dissolved MeHg just below the sediment-water

677 interface in Basins A and B (Figs. 3m, o-p and 5), that $R_{a d s}^{\mathrm{MeHg}}$ and $R_{\text {methyl }}^{\mathrm{MeHg}}$ can be neglected in Eq.

678 (3), and that demethylation rate is first order with respect to [MeHg], then:

679

$680 R_{\text {net }}^{\mathrm{MeHg}}=R_{\text {demethyl }}=-\phi k_{\text {demethyl }}[\mathrm{MeHg}]_{a v}$

681

682 where $k_{\text {demethyl }}\left(\mathrm{d}^{-1}\right)$ is the apparent first-order rate constant for demethylation and the subscript " $a v^{\prime \prime}$

683 indicates that the average value over the thickness of the zone is taken into account because $R_{\text {net }}^{\mathrm{MeHg}}$

684 is a piecewise constant function. On this basis, we calculate that $k_{\text {demethyl }}$ varies between $0.04 \mathrm{~d}^{-1}$

685 and $0.3 \mathrm{~d}^{-1}$ in Basin A and between $0.1 \mathrm{~d}^{-1}$ and $0.8 \mathrm{~d}^{-1}$ in Basin B. These field-derived rate constant

686 values are slightly lower than that $\left(1.1 \mathrm{~d}^{-1}\right)$ reported by Merritt and Amirbahman (2008) for the

687 Penobscot River estuary. They can also be compared with those recently obtained in laboratory

688 experiments where sediments or lake water samples were simultaneously spiked with low amounts

689 of $\mathrm{Hg}(\mathrm{II})$ and $\mathrm{MeHg}$ labelled with different stable $\mathrm{Hg}$ isotopes and incubated. These experiments

690 allowed the rate constants to be determined simultaneously for the $\mathrm{MeHg}$ demethylation and $\mathrm{Hg}$

691 methylation processes. The laboratory-derived $k_{\text {demethyl }}$ values reported vary between $0.4 \mathrm{~d}^{-1}-0.5 \mathrm{~d}^{-1}$

692 for lake sediments (Hintelmann et al., 2000), $0.02 \mathrm{~d}^{-1}-0.2 \mathrm{~d}^{-1}$ for estuarine sediments (Rodriguez

693 Martin-Doimeadios et al., 2004) and $0.03 \mathrm{~d}^{-1}-0.05 \mathrm{~d}^{-1}$ for lake water (Eckley et al., 2005). Thus,

694 our $k_{\text {demethyl }}$ values fall within the range reported for these various aquatic environments.

695 Hintelmann et al. (2000) have shown that the rate constants for MeHg demethylation obtained by

696 this approach do not depend on the chemical form of the MeHg spike, i.e., that the MeHg tracer

697 behaves similarly to the $\mathrm{MeHg}$ produced in the natural environment studied. It should be noted that 
698 the MeHg demethylation rate constant $\left(7 \times 10^{-5} \mathrm{~d}^{-1}\right)$ calculated from the decrease with depth of the

$699\{\mathrm{MeHg}\}$ in Basin A sediments (Fig. 4e) is much lower than the values obtained by modeling the

700 porewater profiles. It indicates that $\mathrm{MeHg}$ in the solid phase is not at equilibrium with the

701 dissolved $\mathrm{MeHg}$. We hypothesize that solid-phase $\mathrm{MeHg}$ was already incorporated within

702 sediment particles (e.g., phytoplankton, bacteria) when they were deposited and not simply

703 adsorbed onto them; demethylation of $\mathrm{MeHg}$ was then controlled by sediment particle degradation.

704 The presence of measurable $\{\mathrm{MeHg}\}$ in Basin $\mathrm{A}$ and $\mathrm{B}$ sediments (Fig. 4e, f) at depths where $\mathrm{SO}_{4}$

705 is exhausted supports the slow demethylation of solid phase MeHg. Indeed, methanogenic bacteria

706 have not been reported to methylate $\mathrm{Hg}$. Also, Hintelmann et al. (2000) have shown that amending

707 sediments with sulfide prevents $\mathrm{MeHg}$ demethylation.

708

709 If we assume, for the zone of net porewater MeHg production below that of consumption in

710 Basin A, that $R_{a d s}^{M e H g}$ and $R_{d e m e t h y l}^{M e H g}$ can be neglected in Eq. (3), we obtain:

711

712

$R_{\text {net }}^{\mathrm{MeHg}}=R_{\text {methyl }}^{\mathrm{Hg}}=\phi k_{\text {methyl }}\left[\mathrm{Hg}_{\mathrm{T}}\right]_{a v}$

713

714 where $k_{\text {methyl }}\left(\mathrm{d}^{-1}\right)$ is the apparent first-order rate constant for $\mathrm{Hg}$ methylation. It should be noted

715 that the $\mathrm{Hg}$ methylation rate is expressed in term of $\left[\mathrm{Hg}_{\mathrm{T}}\right]$ to allow comparison with $k_{\text {methyl }}$ values

716 reported in $\mathrm{Hg}$-spiked laboratory experiments. Our field-derived $k_{\text {methyl }}$ values calculated using Eq.

717 (5) range between $0.006 \mathrm{~d}^{-1}$ and $0.1 \mathrm{~d}^{-1}$. To the best of our knowledge, no other study has reported

718 field-derived $k_{\text {methyl }}$ values. However, laboratory-derived values of this rate constant have been

719 obtained in the double spike experiments described above; they vary from $0.001 \mathrm{~d}^{-1}$ to $0.02 \mathrm{~d}^{-1}$ for 
720 lake sediments (Hintelmann et al., 2000), $0.001 \mathrm{~d}^{-1}$ to $0.03 \mathrm{~d}^{-1}$ for estuarine sediments (Rodriguez

721 Martin-Doimeadios et al., 2004) and $0.01 \mathrm{~d}^{-1}$ to $0.09 \mathrm{~d}^{-1}$ for lake water (Eckley et al., 2005). Thus,

722 our field-derived values are of similar magnitude to those obtained in laboratory assays. Such

723 comparison should, however, be taken with caution since the chemical form of the $\mathrm{Hg}$ (II) spike

724 can affect the $\mathrm{Hg}$ methylation rate, i.e., the $\mathrm{Hg}(\mathrm{II})$ spiked could be more available to methylation

725 than the ambient $\mathrm{Hg}$ (Hintelmann et al., 2000).

726

727 4.3. Effect of diagenesis on the solid-phase $\mathrm{Hg}_{\mathrm{T}}$ concentrations

728

729 In environments where sediment mixing is negligible, the measured $f g_{T}$ th a sediment layer 730 represents the sum of the $\mathrm{Hg}_{\mathrm{T}}$ concentration in the settling particles at deposition time and of the

$731 \mathrm{Hg}_{\mathrm{T}}$ concentration released from or added to the sediments during burial. The latter fraction of $\mathrm{Hg}_{\mathrm{T}}$

732 in the sediments, hereafter called diagenetic $\mathrm{Hg}_{\mathrm{T}}\left(\mathrm{Hg}_{\text {diag }}\right.$ ), can be quantified as follows. Equation

733 (6) is first used to relate the removal/production rate of $H g_{T}$ to that of $H g_{T}$ Zain/loss (Laforte

734 et al., 2005; Chappaz et al., 2010):

735

$736 \quad R_{\text {net }}^{H g}=\phi\left(\frac{d \mid H g_{T}}{d t}\right)_{\text {reaction }}=-m\left(\frac{d \# g_{T}}{d t}\right)_{\text {reaction }}$

737

738 where $m$ is the dry bulk density ( $\mathrm{g} \mathrm{cm}^{-3}$ of whole sediment) and the subscript "reaction" indicates

739 reaction rates in solid and solution phases. From Eq. (6), we can then obtain: 
$741 \quad d \quad H g_{T} \frac{7}{\jmath}-\frac{R_{n e t}^{H g}}{m} d t=-\frac{R_{n e t}^{H g}}{m v_{s}} d x$

742

743 and

744

$745 \quad \forall g_{\text {diag }} \frac{7}{\mathcal{J}}-\int_{x=0}^{x=x_{i}} \frac{R_{\text {net }}^{H g}}{m v_{s}} d x \approx-\sum_{x=0}^{x=x_{i}} \frac{R_{\text {net }}^{H g}}{m v_{s}} \Delta x$

746

747 where $v_{s}$ is sedimentation rate $\left(\mathrm{cm} \mathrm{s}^{-1}\right.$; Table 1$)$ and $x_{i}$ is the depth of the sediment layer (maximum

748 depth corresponds to the deepest horizon of collected porewater samples, i.e. $10 \mathrm{~cm}$ ).

749

750 Calculations made with Eq. (8) show that $H g_{\text {diag }}$ represents at the most $0.02 \mathrm{nmol} \mathrm{g}^{-1}(0.9 \%$

751 of $H g_{T}$ ) and $0.11 \mathrm{nmol} \mathrm{g}^{-1}$ (3.8\% of $\left.f g_{T}\right)$ in Basins A and B, respectively. These

752 concentrations are within our analytical precision (5\%). We therefore conclude that post-

753 depositional redistribution of $\mathrm{Hg}$ in Lake Tantaré sediments is negligible and that the measured

$754 \quad H g_{T}$ Profiles reflect $\mathrm{Hg}$ concentrations in the settling particles at deposition time and not

755 diagenesis.

756

757 4.4. Present-day inputs of $\mathrm{Hg}_{\mathrm{T}}$ and $\mathrm{MeHg}$ to the sediments

758

759 The present-day total flux responsible for $\mathrm{Hg}_{\mathrm{T}}$ accumulation in the sediments $\left(J_{A c c}^{\mathrm{Hg}}\right)$ of Lake

760 Tantaré Basin A is the sum of the fluxes of $\mathrm{Hg}_{\mathrm{T}}$ deposited at the sediment surface with settling 
particles $\left(J_{D e p}^{H g}\right)$ and those of dissolved $\mathrm{Hg}_{\mathrm{T}}$ transported across the sediment-water interface by

762 molecular diffusion $\left(J_{D}^{H g}\right)$, bioirrigation $\left(J_{I}^{H g}\right)$ and bioturbation $\left(J_{B}^{H g}\right)$ :

763

$764 J_{A c c}^{H g}=J_{D e p}^{H g}+J_{D}^{H g}+J_{I}^{H g}+J_{B}^{H g}$

765

766 In the seasonally anoxic Basin $\mathrm{B}, J_{A c c}^{H g}$ can be reduced to:

767

768

$J_{A c c}^{H g}=J_{D e p}^{H g}+J_{D}^{H g}$

769

770

The present-day values of $J_{D e p}^{H g}$ for the two basins were obtained by multiplying the sediment mass

771 accumulation rate $\left(\omega ; \mathrm{mg} \mathrm{cm}^{-2} \mathrm{yr}^{-1}\right)$ obtained from the ${ }^{210} \mathrm{~Pb}$ geochronology for the top $0.5 \mathrm{~cm}$

772 sediment layer by the measured $\# g_{T}$ n that layer, which was shown previously (section 4.3) to

773 represent $\mathrm{Hg}$ concentration in settling particles. The values of $J_{D}^{H g}, J_{I}^{H g}$ and $J_{B}^{H g}$ were calculated

774 with the code PROFILE (Table 4). The flux of dissolved $\mathrm{Hg}_{\mathrm{T}}$ is on the order of $0.8 \times 10^{-21} \mathrm{~mol} \mathrm{~cm}^{-}$

$775{ }^{2} \mathrm{~s}^{-1}$ and $40 \times 10^{-21} \mathrm{~mol} \mathrm{~cm}^{-2} \mathrm{~s}^{-1}$ in Basins A and B, respectively, representing less than $9 \%$ of $J_{A c c}^{\mathrm{Hg}}$

776 (Table 4). Thus, most of the $\mathrm{Hg}_{\mathrm{T}}$ is deposited to sediment surface with settling particles, a

777 conclusion that is consistent with the negligible contribution of $H g_{\text {diag }}$ to the measured $\mathbf{H g}$

778

779 Similarly, present-day fluxes of MeHg can be calculated with Eqs. (9) and (10), where $\mathrm{Hg}$

780 fluxes were replaced by MeHg fluxes (Table 5). The results indicate that, in Basin A, most (>97\%)

781 of the $\mathrm{MeHg}$ measured at the sediment surface is at the present time deposited with settling 
782 particles. This conclusion is consistent with our previous calculations (see section 4.2) showing

783 that less than $2 \%$ of $\{\mathrm{MeHg}\}$ in the top sediment layer $(0-0.5 \mathrm{~cm})$ is associated with authigenic $\mathrm{Fe}-$

784 ox and its associated organic matter. In contrast, in Basin B, the diffusive flux of MeHg into the

785 sediments $\left(J_{D}^{\mathrm{MeHg}}\right)$ is of similar magnitude to that of $\mathrm{MeHg}$ deposition with settling particles

$786\left(J_{D e p}^{M e H g}\right)$. Therefore, sediments of both Basins A and B act as a sink for water column MeHg.

\subsection{Recent history of anthropogenic Hg deposition}

789

790

Interpretation of $\left\{\mathrm{Hg}_{\mathrm{T}}\right\}$ profiles in terms of $\mathrm{Hg}$ emission chronology is complex because

791

diagenetic reactions, variations in sediment mass accumulation rate $(\omega)$, lake internal processes, as well as variations in $\mathrm{Hg}$ inputs from the watershed also contribute to shape the $\left\{\mathrm{Hg}_{\mathrm{T}}\right\}$ profiles. In Lake Tantaré Basins A and B sediments, as in other lake sediments (Fitzgerald et al., 1998; Lockhart et al., 2000; Rydberg et al., 2008), diagenetic reactions do not appear to affect the $\left\{\mathrm{Hg}_{\mathrm{T}}\right\}$ records significantly. In the following discussion, it is thus assumed that they also have a negligible influence on Lakes Bédard and Holland $\hbar g_{T}$ J Jecords. In order to take into account variations in $\omega$, the results can be expressed as fluxes $\left(\mathrm{pmol} \mathrm{cm} \mathrm{cr}^{-1}\right)$. The flux of anthropogenic equation:

800

801

$$
J^{H g-A n t h}=H g_{T}-H g_{T}{ }_{1850} \omega
$$


803 where $A g_{T} \underset{1 \$ 50}{7}$ is the average pre-1850 $A g_{T}$. Pespite differences in the magnitude of the

804 fluxes, the $J^{H g-A n t h}$ profiles become quite similar in shape in Basins A and B (see inset in Fig. 6a),

805 in sharp contrast to the $7 g_{T}$ Profiles (Fig 4a, b). Lastly, in order to attenuate the effects of lake

806 specific processes, such as sediment focusing and loss of material via the lake outflow, $J^{\text {Hg-Anth }}$

807 has been corrected as follows (Kada and Heit, 1992):

808

$809 \quad J_{C o r}^{H g-A n t h}=J^{H g-A n t h} \times\left(\frac{I_{\text {Atm }}^{210 P b}}{I_{\text {Sed }}^{210 P b}}\right)$

810

811 where $J_{C o r}^{H g-A n t h}$ is the flux of anthropogenic $\mathrm{Hg}$ corrected for the internal lake processes, $I_{\text {Sed }}^{210 P b}$ is

812 the inventory of unsupported ${ }^{210} \mathrm{~Pb}$ in the sediment cores (Table 1) and $I_{A t m}^{210 P b}$ is the cumulative

813 atmospheric input of ${ }^{210} \mathrm{~Pb}$, which can be assumed to be identical to the average inventory of ${ }^{210} \mathrm{~Pb}$

814 unsupported by the radioactive decay of ${ }^{226} \mathrm{Ra}$ in soils of the Precambrian Shield in Eastern Ontario

815 (0.44 $\mathrm{Bq} \mathrm{cm}^{-2}$; Cornett et al., 1984). The implicit assumption to this frequently applied correction

816 used to interpret the $\mathrm{Hg}_{\mathrm{T}}$ records in lake sediments (e.g. Engstrom and Swain, 1997; Lamborg et

817 al., 2002; Perry et al., 2005; Sunderland et al., 2008; Muir et al., 2009; Yang et al., 2010), is that

818 transport of $\mathrm{Hg}$ to the sediment is similar to that of unsupported ${ }^{210} \mathrm{~Pb}$. Such an assumption is

819 reasonable considering that both $\mathrm{Hg}$ and ${ }^{210} \mathrm{~Pb}$ are particle-reactive elements. We infer that the

$820 J_{\text {Cor }}^{\mathrm{Hg}-\mathrm{Anth}}$ chronologies reflect essentially variations in atmospheric $\mathrm{Hg}$ emissions and watershed

821 contributions of previously deposited atmospheric $\mathrm{Hg}$. 
The chronological variations in $J_{\text {Cor }}^{H g-A n t h}$ for the past 125 years are displayed in Fig. 6 for all

824

825

826

827

828

study lakes. An interesting feature resulting from this data treatment is the good match between the $J_{\text {Cor }}^{H g-\text { Anth }}$ chronologies of Lake Tantaré Basins A and B (Fig. 6a). It should be noted that this good match is not compromised by the fact that $\mathrm{Hg}$ accumulation in Basin B sediments is presently incomplete due to the current diffusion of dissolved $\mathrm{Hg}_{\mathrm{T}}$ into the sediments (Fig. 3k-1) and its fixation over the top $5 \mathrm{~cm}$ of sediments. Indeed, calculations reveal that this process would increase the values of $J_{C o r}^{H g-A n t h}$ by less than $6 \%$ if diffusion continues at the same rate until the sediment is buried below $5 \mathrm{~cm}$ depth. The good match among the $J_{C o r}^{\mathrm{Hg}-\text { Anth }}$ records of the two basins supports our finding regarding the negligible effect of diagenetic reactions on the $\mathrm{Hg}_{\mathrm{T}}$ concentrations in Lake Tantaré sediments. It also suggests that normalization based on the ${ }^{210} \mathrm{~Pb}$ inventory is a valuable approach to correct $\mathrm{Hg}_{\mathrm{T}}$ records for lake specific processes.

The reconstructed records of $J_{C o r}^{H g-A n t h}$ for Lake Tantare Basins A and B reveal that this flux significantly increased since the end of the $19^{\text {th }}$ Century, reached a maximum in the early 1970 s $\left(\sim 14 \mathrm{pmol} \mathrm{cm}^{-2} \mathrm{yr}^{-1}\right)$, and then slightly decreased by about $15 \%$ during the next 30 years. This temporal trend is coherent with that observed in other studies using lake sediments as archive of environmental contamination in North America (e.g. Engstrom and Swain, 1997; Kamman and Engstrom, 2002; Perry et al., 2005; Biester et al., 2007; Muir et al., 2009). The increase in $J_{C o r}^{H g-A n t h}$ from the end of the $19^{\text {th }}$ Century to the early 1970 s was attributed to the progressive escalation of industrial activity during that time period in North America (Engstrom and Swain, 1997; Pirrone et al., 1998). Its decline, after the 1970s, was attributed to implementation of new technologies to reduce contaminant emissions at their source, particularly in coal-fired power plants (Pacyna et al., 
845 2006), but also to the political will to diminish the use of $\mathrm{Hg}$ in industrial and commercial products

846 in the U.S., which apparently decreased by more than 75\% between 1988 and 1996 (Engstrom and

847 Swain, 1997; USEPA, 1997). It should be noted that a mere interpretation of the $7 g_{T}$ fecord in

848 Basin A sediments would have suggested an increase after the 1970s of anthropogenic $\mathrm{Hg}$

849 deposition rather than a decrease.

850

851

The present-day value of $J_{C o r}^{H g-A n t h}$ in Basins A and B $\left(\sim 12 \mathrm{pmol} \mathrm{cm}^{-2} \mathrm{yr}^{-1}\right)$ is in the lower

852 range of values found in other studies on the distribution of $\mathrm{Hg}_{\mathrm{T}}$ in dated lake sediment cores

853 fromEastern North America (5-30 $\mathrm{pmol} \mathrm{cm}^{-2} \mathrm{yr}^{-1}$; Perry et al., 2005; Muir et al., 2009). On the

854 other hand, it is higher than the annual mean values of atmospheric $\mathrm{Hg}$ deposition rate due to

855 precipitations at two Southern Québec sites between 1996 and 2006 (2-4 $\mathrm{pmol} \mathrm{cm}^{-2} \mathrm{yr}^{-1}$;

856 VanArsdale et al., 2005; NADP, 2010). This discrepancy between $J_{\text {Cor }}^{H g \text { Anth }}$ and the wet

857 atmospheric deposition of $\mathrm{Hg}$ cannot only be due to the dry atmospheric $\mathrm{Hg}$ deposition which

858 should amount to about $30 \%$ of wet Hg deposition (Lamborg et al., 1995; Selvendiran et al., 2009).

859 It rather suggests that an important part of anthropogenic $\mathrm{Hg}_{\mathrm{T}}$ accumulating in Lake Tantaré

860 sediments is due to watershed inputs of previously deposited atmospheric Hg (e.g. Swain et al.,

861 1992; Grigal, 2002).

862

863 Fig. $6 \mathrm{~b}$ shows that $J_{C o r}^{H g-A n t h}$ has increased in Lake Bédard from the end of the $19^{\text {th }}$ century to the

864 early 1970s, as in Lake Tantaré, but at a much lower rate, which could be attributed at least partly

865 to a lower $\mathrm{Hg}$ contribution from the watershed. It is noteworthy that the catchment area is about 25

866 times smaller in Lake Bédard than in Lake Tantaré. Indeed, several authors have found a

867 significant correlation between the $\mathrm{Hg}$ deposition flux in lake sediments and the catchment area or 
868 the catchment/lake area ratio (e.g. Swain et al., 1992; Kamman and Engstrom, 2002; Mills et al.,

869 2009). Moreover, the type of biomass, the soil composition, and human disturbances in the

870 watershed might also have a strong influence on $\mathrm{Hg}$ export from the watershed to the lake

871 sediments (e.g. Grigal, 2002; Kainz and Lucotte, 2006; Engstrom et al., 2007; Mills et al., 2009).

872 The Lake Tantaré catchment has a mixed forest of St. Lawrence Lowlands (maple, yellow birch)

873 and boreal forest tree species (fir, spruce, white birch; Payette et al., 1990), while vegetation of

874 Lake Bédard catchment is typical of that of the boreal forest (white birch, balsam fir, white spruce,

875 http://www.ffgg.ulaval.ca/index.php?id=346). The importance of the watershed contribution in $\mathrm{Hg}$

876 is further supported by the presence of a $J_{C o r}^{H g-A n t h}$ peak $\left(\sim 7.4 \mathrm{pmol} \mathrm{cm}^{-2} \mathrm{yr}^{-1}\right)$ in the early $1970 \mathrm{~s}$,

877 which occurred concurrently with a 4-fold increase in $\omega$ values which can likely be associated to

878 the construction of a small forest road in the catchment in the late 1960s. We, however, have no

879 clear explanation for the $J_{\text {Cor }}^{\mathrm{Hg} \text {-Anth }}$ increase in Lake Bédard after 1990 which is not correlated with 880 an increase in $\omega$.

881

882 In Lake Holland (Fig. 6c), $J_{\text {Cor }}^{\text {Hg-Anth }}$ increased slowly from the end of the $19^{\text {th }}$ century to the 883 early 1950s and more sharply after this time horizon reaching a maximum value of $\sim 10.3 \mathrm{pmol} \mathrm{cm}^{-}$ $884{ }^{2} \mathrm{yr}^{-1}$ in the early 1990 s, and then progressively decreased by about $50 \%$. This trend clearly shows 885 the imprint of the nearby Murdochville non-ferrous metal smelter. Production at the smelter began 886 in 1950, steadily increased until its temporary shut down during the 1980s. After the 887 implementation of new technologies to reduce contaminant emissions into the atmosphere, it 888 restarted again in 1989 until the smelter was definitely closed in April 2002. However, the fact that 889 the maximum value of $J_{C o r}^{H g-A n t h}$ is observed few years after the smelter was temporary shutdown 890 indicates that part of the anthropogenic $\mathrm{Hg}$ accumulating in Lake Holland sediments was initially 
891 deposited on the watershed and retained for some time in the watershed soils and biomass. Thus,

892 the response of atmospheric deposition of $\mathrm{Hg}$ into Lake Holland was delayed by about 10 years;

893 such a delay is consistent with what has been suggested in other studies (Meili et al., 2003; Perry et

894 al., 2005; Harris et al., 2007; Mills et al., 2009),

895

896

897

\section{CONCLUSIONS}

898

899

We have shown that applying thermodynamic and kinetic modeling to field measurements of

$900 \mathrm{Hg}_{\mathrm{T}}, \mathrm{MeHg}$ and ancillary parameters in sediments and porewaters helps understanding $\mathrm{Hg}_{\mathrm{T}}$ and

901 MeHg dynamics in sediments. Hence, we provide evidence that pure $\mathrm{Hg}$ mineral phases do not

902 form in the sediments and that $\mathrm{Hg}_{\mathrm{T}}$ and $\mathrm{MeHg}$ adsorption onto authigenic Fe-ox is of minor

903 importance; however, the assessment of $\mathrm{Hg}_{\mathrm{T}}$ and $\mathrm{MeHg}$ association with $\mathrm{Fe}$ sulfide phases or

904 sulfidized organic matter would require additional field and laboratory measurements. Application

905 of the reaction-transport model to the porewater $\mathrm{Hg}_{\mathrm{T}}$ profiles indicates that post-depositional $\mathrm{Hg}_{\mathrm{T}}$

906 redistribution negligibly affects the measured $\mathrm{Hg}_{\mathrm{T}}$ profiles in Lake Tantaré sediments, a lake that is

907 representative of many other Canadian Shield lakes. Thus, the measured sediment $\mathrm{Hg}_{\mathrm{T}}$ profiles

908 reflect the chronology of $\mathrm{Hg}_{\mathrm{T}}$ deposition at the sampling site. Comparison of the results from the

909 two Lake Tantaré basins indicates that normalisation with ${ }^{210} \mathrm{~Pb}$ inventories is both appropriate and

910 necessary to correct the sediment $\mathrm{Hg}_{\mathrm{T}}$ data for internal lake processes. We also provide field

911 evidence that $\mathrm{Hg}$ methylation occurs only when $\mathrm{SO}_{4}$ is consumed. Use of the inverse modeling

912 approach to interpret the porewater MeHg profiles yields estimates of rate constants for the

913 formation and degradation of $\mathrm{MeHg}$ in the sediments; these field-derived rate constants are of 
914 similar magnitude as the recent laboratory-derived rate constants obtained by incubating sediments

915 with $\mathrm{Hg}$ spikes labelled with stable $\mathrm{Hg}$ isotopes. Our results also reveal that sediments act as a sink

916 for $\mathrm{MeHg}$, that most of the MeHg accumulates in sediments deposited under oxic conditions in

917 association with settling particles and that solid-phase $\mathrm{MeHg}$ is slowly degraded subsequent to 918 deposition.

919

920

\section{ACKNOWLEDGMENTS}

921

922 Financial support from the Natural Sciences and Engineering Research Council of Canada and 923 the Fonds de Recherche sur la Nature et les Technologies du Québec are acknowledged. We thank

924 L. Rancourt, R. Rodrigue, P. Fournier and B. Averty for their technical assistance and two 925 anonymous reviewers for critical comments. Permission from the Québec Ministère de

926 l'Environnement to work in the Tantaré Ecological Reserve and from Faune et Parcs Québec to 927 work in the Aiguebelle Provincial Park are gratefully acknowledged.

928 


\section{REFERENCES}

930

931 Alfaro-De La Torre M. C. and Tessier A. (2002) Cadmium deposition and mobility in the sediments of an acidic oligotrophic lake. Geochim. Cosmochim. Acta 66, 3549-3562.

Belzile N., De Vitre R. R. and Tessier A. (1989) In situ collection of diagenetic iron and manganese oxhydroxides from natural sediments. Nature 340, 376-377.

Belzile N., Lang C.-Y., Chen Y.-W. and Wang M. (2008) The competitive role of organic carbon and dissolved sulfide in controlling the distribution of mercury in freshwater lake sediments. Sci. Total Environ. 405, 226-238.

Benoit J. M., Gilmour C. C., Heyes A., Mason R. P. and Miller C. L. (2003) Geochemical and biological controls over methylmercury production and degradation in aquatic ecosystems. In: Cai Y. and Braids O. C., (Eds.) Biogeochemistry of Environmentally Important Trace Elements, ACS Symp. Ser. 835, 262-297. American Chemical Society, Washington D.C.

Berg P., Risgaard-Petersen N. and Rysgaard S. (1998) Interpretation of measured concentration profiles in sediment porewater. Limnol. Oceanogr. 43, 1500-1510.

Berner R. A. (1980) Early Diagenesis: a Theoretical Approach. Princeton University Press.

Biester H., Bindler R., Martinez-Cortinas A. and Engstrom D. R. (2007) Modeling the past atmospheric deposition of mercury using natural archives. Environ. Sci. Technol. 41, 48514860.

Bloom N. S. and Fitzgerald W. F. (1988) Determination of volatile mercury species at picogram level by low temperature gas chromatography with cold-vapour atomic fluorescence detection. Anal. Chim. Acta 28, 151-161. 
951 Bloom N. S., Gill G. A., Capellino S., Dobbs C., McShea L., Driscoll C., Mason R. and Rudd J. (1999) Speciation and cycling of mercury in Lavaca Bay. Environ. Sci. Technol. 33, 7-13.

953 Boudreau B. P. (1984) On the equivalence of nonlocal and radial-diffusion models for porewater 954 irrigation. J. Mar. Res. 42, 731-735.

955 Boudreau B. P. (1997) Diagenetic Models and their Implementation. Springer-Verlag.

956 Buffle J. (1988) Complexation Reactions in Aquatic Systems. Ellis Horwood Ltd.

957 Canfield D., Boudreau B. P., Mucci A. and Gundersen J. K. (1998) The early diagenetic formation 958 of organic sulfur in the sediments of Mangrove Lake, Bermuda. Geochim. Cosmochim. $959 \quad$ Acta 62, 767-781.

960 Carignan R., St-Pierre S. and Gächter R. (1994) Use of diffusion samplers in oligotrophic lake 961 sediments: effects of free oxygen in sampler material. Limnol. Oceanogr. 39, 468-474.

962 Chappaz A., Gobeil C. and Tessier A. (2008) Geochemical and anthropogenic enrichments of Mo 963 in sediments from perennially oxic and seasonally anoxic lakes in Eastern Canada. 964 Geochim. Cosmochim. Acta 72, 170-184.

965 Chappaz A., Gobeil C. and Tessier A. (2010) Controls on uranium distribution in lake sediments. 966 Geochim Cosmochim. Acta 74, 203-214.

967 Compeau G. C. and Bartha R. (1985) Sulfate-reducing bacteria: principal methylators of mercury 968 in anoxic estuarine sediment. Appl. Environ. Microbiol. 50, 498-502.

969 Cornett R. J., Chant L. and Link D. (1984) Sedimentation of Pb-210 in Laurentian Shield lakes. $970 \quad$ Water Poll. Res. J. Canada 19, 97-109.

971 Cossa D., Coquery M., Nakhlé K. and Claisse D. (2002) Dosage du mercure total et du 972 monométhylmercure dans les organismes et les sédiments marins. Editions Ifremer284433-105-X; 27pp. 
974 Cossa D., Averty B. and Pirrone N. (2009) The origin of methylmercury in open Mediterranean

975

976

977

978

979

980

981

982

983

984

985

986

987

988

989

990

991

992

993

994 waters. Limnol. Oceanogr. 54, 837-844.

Couture R.-M., Gobeil C. and Tessier A. (2008) Chronology of atmospheric deposition of arsenic inferred from reconstructed sedimentary records. Environ. Sci. Technol. 42, 6508-6513.

Couture R.-M., Gobeil C. and Tessier A. (2010a) Arsenic, iron and sulfure co-diagenesis in lake sediments. Geochim. Cosmochim. Acta 74, 1238-1255.

Couture R.-M., Shafei B., Van Cappellen P., Tessier A. and Gobeil C. (2010b) Non-steady state modeling of arsenic diagenesis in lake sediments. Environ. Sci. Technol. 44, 197-203.

De Robertis A., Foti C., Patane G. and Sammartano S. (1998) Hydrolysis of $\left(\mathrm{CH}_{3}\right) \mathrm{Hg}^{+}$in different ionic media: salt effects and complex formation. J. Chem. Eng. Data 43, 957-960.

Eckley C. S., Watras C. J., Hintelmann H., Morrison K., Kent A. D. and Regnell O. (2005) Mercury methylation in the hypolimnetic waters of lakes with and without connection to wetlands in northern Wisconsin. Can. J. Fish. Aquat. Sci. 62, 400-411.

Einsield F., Mayer B. and Schäfer T. (2008) Evidence for incorporation of $\mathrm{H}_{2} \mathrm{~S}$ in groundwater fulvic acids from stable isotope ratios and sulfur K-edge X-ray absorption near edge structure spectroscopy. Environ. Sci. Technol. 42, 2439-2444.

Engstrom D. R., Balogh S. J. and Swain E. B. (2007) History of mercury inputs to Minnesota lakes: influences of watershed disturbance and localized atmospheric deposition. Limnol. Oceanogr. 52, 2467-2683.

Engstrom D. R. and Swain E. B. (1997) Recent declines in atmospheric mercury deposition in the Upper Midwest. Environ. Sci. Technol. 31, 960-967. 
995 Ethier A. L. M., Scheuhammer A. M., Blais J. M., Paterson A. M., Mierle G., Ingram R. and Lean D. R. S. (2010) Mercury empirical relationships in sediments from three Ontario lakes. Sci. Total Environ. 408, 2087-2095.

Evers D. C., Kaplan J. D., Meyer M. W., Reaman P. S., Braselton W. E., Major A., Burgess N. and 999 Scheuhammer A. M. (1998) Geographic trend in mercury measured in common loon 1000 feathers and blood. Environ. Toxicol. Chem. 17, 173-183. Geochem. 25, 984-995.

Fitzgerald W. F., Engstrom D. R., Lamborg C. H., Tseng C.-M., Balcom P. H. and Hammerschmidt C. R. (2005) Modern and historic atmospheric mercury in Northern mercury contamination in remote areas. Environ. Sci. Technol. 32, 1-7.

1009 Fitzgerald W. F., Lamborg C. H. and Hammerschmidt C. R. (2007) Marine biogeochemical $1010 \quad$ cycling of mercury. Chem. Rev. 107, 641-662.

1011 Fortin D., Leppard G. G. and Tessier A. (1993) Characteristics of lacustrine diagenetic iron $1012 \quad$ oxyhydroxides. Geochim. Cosmochim. Acta 57, 4391-4404.

1013 Gagnon C., Pelletier É. and Mucci A. (1997) Behavior of anthropogenic mercury in coastal marine 1014 sediments. Mar. Chem. 59, 159-176.

1015 Gallon C., Tessier A., Gobeil C. and Alfaro-De La Torre M. C. (2004) Modeling diagenesis of lead 1016 in sediments of a Canadian Shield lake. Geochim. Cosmochim. Acta 68, 3531-3545. 
1017 Gill G. A., Bloom N. S., Cappellino S., Driscoll C. T., Dobbs C., McShea L., Mason R. and Rudd

1018 J. W. M. (1999) Sediment-water fluxes of mercury in Lavaca Bay, Texas. Environ. Sci.

1019 Technol. 33, 663-669.

1020 Gilmour C. C., Henry E. A. and Mitchell R. (1992) Sulfate stimulation of mercury methylation in 1021 freshwater sediments. Environ. Sci. Technol. 26, 2281-2287.

1022 Gobeil C. and Cossa D. (1993) Mercury in sediments and sediment porewater in the Laurentian 1023 Through. Can. J. Fish. Aquat. Sci. 50, 1794-1800.

1024 Goulet R., Holmes J., Page B., Poissant L., Siciliano S. D., Lean D. R. S., Wang F., Amyot M. and 1025 Tessier A. (2007) Mercury transformations and fluxes in sediments of a riverine wetland. 1026 Geochim. Cosmochim. Acta 71, 3393-3406.

1027 Grigal D. F. (2002) Inputs and outputs of mercury from terrestrial watersheds: a review. Environ. $1028 \quad$ Rev. 10, 1-39.

1029 Gunneriusson L. D., Baxter D. and Emteborg H. (1995) Complexation at low concentrations of 1030 methyl and inorganic mercury(II) to a hydrous goethite $(\alpha-\mathrm{FeOOH})$ surface. J. Coll. Interf. Sci. 169, 262-266.

Hamilton-Taylor J., Willis M., Reynold C. S. (1984) Depositional fluxes of metals and phytoplankton in Windermere as measured by sediment traps. Limnol. Oceanogr. 29, 695710.

Hammerschmidt C. R. and Fitzgerald W. F. (2004) Geochemical controls on the production and distribution of methylmercury in near-shore marine sediments. Environ. Sci. Technol. 38, 1487-1495.

Hammerschmidt C. R. and Fitzgerald W. F. (2006a) Methylmercury cycling in sediments on the 1039 continental shelf of southern New England. Geochim. Cosmochim. Acta 70, 918-930. 
1040 Hammerschmidt C. R. and Fitzgerald W. F. (2006b) Methylmercury in freshwater fish linked to atmospheric mercury deposition. Environ. Sci. Technol. 40, 7764-7770.

1042 Hammerschmidt C. R., Fitzgerald W. F., Lamborg C. H., Balcom P. H. and Tseng C. M. (2006)

1043 Biogeochemical cycling of methylmercury in lakes and tundra watersheds of Arctic 1044 Alaska. Environ. Sci. Technol. 40, 1204-1211.

1045 Hammerschmidt C. R., Fitzgerald W. F., Lamborg C. H., Balcom P. H. and Visscher P. T. (2004) Biogeochemistry of methylmercury in sediments of Long Island Sound. Mar. Chem. 90, $31-52$.

Hare L., Carignan R. and Huerta-Diaz M. A. (1994) A field study of metal toxicity and accumulation by benthic invertebrates; implications for the acid-volatile sulfide (AVS) model. Limnol. Oceanogr. 39, 1653-1668.

Harris R. C., Rudd J. W. M., Amyot M., Babiarz C. L., Beaty K. G., Blanchfield P. J., Bodaly R. A., Branfireun B. A., Gilmour C. C., Graydon J. A., Heyes A. H. H., Hurley J. P., Kelly C. A., Krabbenhoft D. P., Lindberg S. E., Mason R. P., Paterson M. J., Podemski C. L., Robinson A., Sandilands K. A., Southworth G. R. and St Louis V. L. (2007) Wholeecosystem study shows rapid fish-mercury response to changes in mercury deposition. $P$. Nat. Acad. Sci. 104, 16586-16591.

He T., Lu J., Yang F. and Feng X. (2007) Horizontal and vertical variability of mercury species in pore water and sediments in small lakes in Ontario. Sci. Total Environ. 386, 53-64.

1059 Heyes A., Miller C. and Mason R. P. (2004) Mercury and methylmercury in Hudson River 1060 sediment: impact of tidal resuspension on partitioning and methylation. Mar. Chem. 90, 7589. 
1062 Hines N. A., Brezonik P. L. and Engstrom D. R. (2004) Sediment and porewater profiles and 1063 fluxes of mercury and methylmercury in a small seepage lake in northern Minnesota. 1064 Environ. Sci. Technol. 38, 6610-6617.

1065 Hintelmann H., Keppel-Jones K. and Evans R. D. (2000) Constants of mercury methylation and 1066 demethylation rates in sediments and comparison of tracer and ambient mercury availability. Environ. Toxicol. Chem. 19, 2204-2211.

Hintelmann H., Welbourn P. M. and Evans R. D. (1997) Measurement of complexation of methylmercury(II) compounds by freshwater humic substances using equilibrium dialysis. Environ. Sci. Technol. 31, 489-495.

Hollweg T. A., Gilmour C. C. and Mason R. P. (2009) Methylmercury production in sediments of 1072 Chesapeake Bay and the mid-Atlantic continental margin. Mar. Chem. 114, 86-101.

1073 Jay J. A., Morel F. M. M. and Hemond H. F. (2000) Mercury speciation in the presence of polysulfides. Environ. Sci. Technol. 34, 2196-2200.

1075

Jeong H. Y., Klaue B., Blum J. D. and Hayes K. F. (2007) Sorption of mercuric ion by synthetic nanocrystalline mackinawite (FeS). Environ. Sci. Technol. 41, 7699-7705.

Kada J. and Heit M. (1992) The inventories of anthropogenic Pb, Zn, As, Cd, and the 1078 radionuclides ${ }^{137} \mathrm{Cs}$ and excess ${ }^{210} \mathrm{~Pb}$ in lake sediments of the Adirondack region, USA. Hydrobiologia 246, 231-241.

1080 Kainz and Lucotte (2006) Mercury concentrations in lake sediments - revisiting the predictive 1081 power of catchment morphometry and organic matter composition. Water Air Soil Poll. 170, 173-189. 
1083 Kainz M., Lucotte M. and Parrish C. C. (2003) Relationships between organic matter composition and methylmercury content of offshore and carbon-rich littoral sediments in an oligotrophic lake. Can J. Fish. Aquat. Sci. 60, 888-896.

Kamman N. C. and Engstrom D. R. (2002) Historical and present fluxes of mercury to Vermont and New Hampshire lakes inferred from ${ }^{210} \mathrm{~Pb}$ dated sediment cores. Atmos. Environ. 36, 1599-1609.

Karlsson T. and Skyllberg U. (2003) Bonding of ppb levels of methyl mercury to reduced sulfur groups in soil organic matter. Environ. Sci. Technol. 37, 4912-4918. Geochim. Cosmochim. Acta 69, 5295-5306. (1998) Methylmercury dynamics in littoral sediments of a temperate seepage lake. Can. $J$.

Krabbenhoft D. P., Gilmour C. C., Benoit J. M., Babiarz C. L., Andren A. W. and Hurley J. P. Fish. Aquat. Sci. 55, 835-844.

Laforte L., Tessier A., Gobeil C. and Carignan R. (2005) Thallium diagenesis in lake sediments.

Lambertsson L. and Nilsson M. (2006) Organic material: the primary control on mercury methylation and ambient methylmercury concentrations in estuarine sediments. Environ. Sci. Technol. 40, 1822-1829. R. (2002) Modern and historic atmospheric mercury fluxes in both hemispheres: global and regional mercury cycling implications. Global Biogeochem. Cycles 16, 51, 1-11. 
1106 Lamborg C. H., Fitzgerald W. F., Vandal G. M. and Rolfhus K. R. (1995) Atmospheric mercury in 1107 Northern Wisconsin: source and speciation. Water Air Soil Poll. 80, 189-198.

1108 Leermakers M., Galletti S., De Galan S., Brion N. and Baeyens W. (2001) Mercury in the 1109 Southern North Sea and Scheldt estuary. Mar. Chem. 75, 229-248.

1110 Leermakers M., Baeyens W., Quevauviller P. and Horvat M. (2005) Mercury in environmental 1111 samples: speciation, artifacts and validation. Trends Anal. Chem. 24, 383-393.

1112 Liu J., Valsaraj K. T., Devai I. and DeLaune R. D. (2008) Immobilization of aqueous Hg(II) by 1113 mackinawite (FeS). J. Hazard. Mater. 157, 432-440.

1114 Lockhart W. L., Macdonald R. W., Outridge P. M., Wilkinson P., DeLaronde J. B. and Rudd J. W. 1115 M. (2000) Tests of the fidelity of lake sediment core records of mercury deposition to 1116 known histories of mercury contamination. Sci. Total Environ. 260, 171-180.

1117 Loux N. T. (2007) An assessment of thermodynamic reaction constants for simulating aqueous 1118 environmental monomethylmercury speciation. Chem. Spec. Bioavailab. 19, 183-196.

1119 Malcolm R. L. (1985) Geochemistry of stream fulvic and humic substances. In Humic Substances 1120 in Soil, Sediment and Water. Geochemistry, Isolation and Characterization (ed. G. R. $1121 \quad$ Aiken et al.), pp. 181-209. Wiley-Interscience.

1122 Martell A. E. and Smith R. M. (2001) NIST Critically Selected Stability Constants of Metal 1123 Complexes, version 6 Gaithersburg, Maryland: National Institute of Standards and 1124 Technology.

1125 Martell A. E., Smith R. M. and Motekaitis R. J. (2003) NIST critical constants for metal 1126 complexes. NIST Standard Reference Database 46, U.S. Department of Commerce, 1127 National Institute of Standards and Technology, Gaithersburgh, MD. 
1128 Marvin-Di Pasquale M. C., Agee J., McGowan C., Oremland R. S., Thomas M., Krabbenhoft D. and Gilmour C. C. (2000) Methylmercury degradation pathways: a comparison among three mercury-impacted ecosystems. Environ. Sci. Technol. 34, 4908-4916.

Matisoff G. and Wang X. (1998) Solute transport in sediments by freshwater infaunal bioirrigators. Limnol. Oceanogr. 43, 1487-1499.

1133 Matisoff G. and Wang X. (2000) Particle mixing by freshwater infaunal bioirrigators: midges 1134 (chironomidae: diptera) and mayflies (ephemeridae: ephemeroptera). J. Great Lakes Res. 26, 174-182.

Meili M., Bishop K., Bringmark L., Johansson K., Munthe J., Sverdrup H. and De Vries W. (2003) Critical levels of atmospheric pollution: criteria and concepts for operational modelling of mercury in forest and lake ecosystems. Sci. Total Environ. 304, 83-106.

Merritt K. A. and Amirbahman A. (2007) Mercury dynamics in sulfide-rich sediments: geochemical influence on contaminants mobilization within the Penobscot River estuary, Maine, USA. Geochim. Cosmochim. Acta 71, 929-941.

1142 Merritt K. A. and Amirbahman, A. (2008) Methylmercury cycling in estuarine sediment pore waters (Penobscot River estuary, Maine, USA). Limnol. Oceanogr. 53, 1064-1075.

1144 Miller C. L. (2006) The role of organic matter in the dissolved phase speciation and solid phase partitioning of mercury. $\mathrm{PhD}$ thesis. University of Maryland, College Park.

Mills R. B., Paterson A. M., Blais J. M., Lean D. R. S., Smol J. P. and Mierle G. (2009) Factors influencing the achievement of steady state in mercury contamination among lakes and catchments of south-central Ontario. Can. J. Fish. Aquat. Sci. 66, 187-200.

1149 Morse J. W. and Luther G. W. (1999) Chemical influences on trace metal-sulfide interactions in anoxic sediments. Geochim. Cosmochim. Acta 63, 3373-3378. 
1151 Muir D. C. G., Wang X., Yang F., Nguyen N., Jackson T. A., Evans M. S. D. M., Köck G.,

1152 Lamoureux S., Pienitz R., Smol J. P., Vincent W. F. and Dastoor A. (2009) Spatial trends

1153 and historical deposition of mercury in Eastern and Northern Canada inferred from lake

$1154 \quad$ sediment cores. Environ. Sci. Technol. 43, 4802-4809.

1155 Munthe J., Bodaly R. A., Branfireun B. A., Driscoll C. T., Gilmour C. C., Harris, R, Horvat M.,

1156 Lucotte M. and Malm O. (2007) recovery of mercury-contaminated fisheries. Ambio 36,

$1157 \quad 33-44$.

1158 NADP (2010) Mercury Deposition Network Public Database. http://nadp.sws.uiuc.edu/mdn.

1159 National Atmospheric Deposition Program Office, Illinois State Water Survey, Champaign,

$1160 \quad$ IL.

1161 Newhook R., Hirtle H., Byrne K. and Meek M. E. (2003) Release from copper smelters and

1162 refineries and zinc plants in Canada: Human health exposure and risk characterization. Sci.

1163 Total Environ. 301, 23-41.

1164 Olson B. H. and Cooper R. C. (1974) In situ methylation of mercury in estuarine sediments.

$1165 \quad$ Nature 252, 682-683.

1166 Oremland R. S., Culberton C. W. and Winfrey M. R. (1991) Methylmercury decomposition in 1167 sediments and bacterial cultures: involvement of methanogens and sulphate reducers in 1168 oxidative demethylation. Appl. Environ. Microbiol. 57, 130-137.

1169 Pacyna E. G., Pacyna J. M., Steenhuisen F. and Wilson S. (2006) Global anthropogenic mercury 1170 emission inventory for 2000. Atmos. Environ. 40, 4048-4063.

1171 Parker J.L. and Bloom N.S. (2005) Preservation and storage techniques for low-level aqueous 1172 mercury speciation. Sci. Tot. Environ. 337, 253-263. 
1173 Payette, D. E., Filion L. and Delwaide A. (1990) Disturbance regime of a cold temperate forest as 1174 deduced from tree-rings patterns: the Tantaré Ecological Reserve, Quebec. Can. J. For. $1175 \quad$ Res. 20, 1228-1241.

1176 Perry E., Norton S. A., Kamman N. C., Lorey P. M. and Driscoll C. T. (2005) Deconstruction of 1177 historic mercury accumulation in lake sediments, Northeastern United States.

$1178 \quad$ Ecotoxicology 14, 85-99.

1179 Pirrone N., Allegrini I., Keeler G. J., Nriagu J. O., Rossmann R. and Robbins J. A. (1998)

1180 Historical atmospheric mercury emissions and depositions in North America compared to 1181 mercury accumulations in sedimentary records. Atmos. Environ. 32, 929-940.

1182 Powell K. J., Brown P. L., Byrne R. H., Gajda T., Hefter G., Sjöberg S. and Wanner H. (2005)

1183 Chemical speciation of environmentally significant heavy metals with inorganic ligands.

1184 Part 1: The $\mathrm{Hg}^{2+}-\mathrm{Cl}^{-}, \mathrm{OH}^{-}, \mathrm{CO}_{3}{ }^{2-}, \mathrm{SO}_{4}{ }^{2-}$, and $\mathrm{PO}_{4}{ }^{2-}$ aqueous systems. Pure Appl. Chem. 77, $1185 \quad 739-800$.

1186 Rabenstein D. L., Touranqueau M. C. and Evans C. A. (1976) Proton magnetic resonance and 1187 Raman spectroscopic studies of methylmercury(II) complexes of inorganic anions. Can. J. $1188 \quad$ Chem. 54, 2517-2525.

1189 Ramlal P. S., Rudd J. W. M. and Hecky R. E. (1986) Methods for measuring specific rates of 1190 mercury methylation and degradation and their use in determining factors controlling net 1191 rates of mercury methylation. Appl. Environ. Microbiol. 51, 110-114.

1192 Ravichandran M. (2004) Interactions between mercury and dissolved organic matter - a review. $1193 \quad$ Chemosphere 55, 319-331. 
1194 Redfield A. C. (1934) On the proportions of organic derivatives in seawater and their relation to 1195 the composition of plankton. In: Daniel, R.J. (Ed.), James Johnson Memorial Volume. $1196 \quad$ Liverpool University Press, Liverpool.

1197 Rickard D. (2006) The solubility of FeS. Geochim. Cosmochim. Acta 70, 5779-5789.

1198 Rodriguez Martin-Doimeadios R. C., Tessier E., Amouroux D., Guyauneaud R., Duran R., 1199 Caumette P. and Donard O. F. X. (2004) Mercury methylation/demethylation and 1200 volatilization pathways in estuarine sediment slurries using species-specific enriched stable 1201 isotopes. Mar. Chem. 90, 107-123.

1202 Rydberg J., Gälman V., Renberg I. and Bindler R. (2008) Assessing the stability of mercury and 1203 methylmercury in a varved lake sediment deposit. Environ. Sci. Technol. 42, 4391-4396.

1204 Selvendiran P., Driscoll C. T., Montesdeoca M. R., Choi H.-D. and Holsen T. M. (2009) Mercury 1205 dynamics and transport in two Adirondack lakes. Limnol. Oceanogr. 54, 413-427. MeHg in wetland soils and sediments under suboxic conditions: illumination of doi: 10.1029/2008JG000745.

1210 Stoichev T., Rodriguez Martin-Doimeadios R. C., Tessier E., Amouroux D. and Donard O. F. X., 1211 (2004) Improvement of analytical performances for mercury speciation by on-line derivatization, cryofocussing and atomic fluorescence spectrometry. Talanta 62, 433-438.

1213 Sunderland E. M., Gobas F. A. P. C., Branfireun B. A. and Heyes, A. (2006) Environmental 1214 controls on the speciation and distribution of mercury in coastal sediments. Mar. Chem.

1215 102, 111-123. 
1216 Sunderland E. M., Cohen M. D., Selin N. E. and Chmura G. L. (2008) Reconciling models and 1217 measurements to assess trends in atmospheric mercury deposition. Environ. Poll. 156, 526535

1219 Swain E. B., Engstrom D. R., Brigham M. E., Henning T. A. and Brezonik P. L. (1992) Increasing 1220 rates of atmospheric mercury deposition in midcontinental North America. Science 257, $1221 \quad 784-787$.

1222 Tiffreau C., Lützenkirchen J. and Behra P. (1995) Modeling the adsorption of mercury(II) on (Hydr)oxides. 1. Amorphous iron oxide and $\alpha$-quartz. J. Coll. Interf. Sci. 172, 82-93.

1224 Tipping E. (2002) Cation Binding by Humic Substances. Cambridge University Press.

1225 Tipping E. (2007) Modelling the interactions of $\mathrm{Hg}(\mathrm{II})$ and methylmercury with humic substances 1226 using WHAM/Model VI. Appl. Geochem. 22, 1624-1635.

1227 Turner A., Millward G. E. and Le Roux S. M. (2004) Significance of oxides and particulate 1228 organic matter in controlling trace metal partitioning in a contaminated estuary. Mar. Chem. 88, 179-192.

1230 Ullrich S. M., Tanton T. W. and Abdrashitova S. A. (2001) Mercury in the aquatic environment: a 1231 review of factors affecting methylation. Crit. Rev. Environ. Sci. Technol. 31, 241-293.

1232 USEPA (1997) Mercury Study Report to Congress. Volume II: An Inventory of Anthropogenic 1233 Emissions in the United States. EPA-452/R-97-004. U.S. Environmental Protection Agency. Office of Air Quality \& Standards and Office of Research and Development.

1235 USEPA (2002) Method 1631, Revision E: Mercury in water by oxidation, purge and trap, and cold 1236 vapor atomic fluorescence spectrometry. EPA-821-R-02-019. U.S. Environmental 1237 Protection Agency, Office of Water. 
1238 USEPA (2007) Method 7473: Mercury in solids and solutions by thermal decomposition,

1239 amalgamation, and atomic absorption spectrophotometry, http://www.epa.gov/osw/hazard/testmethods/sw846/pdfs/7473.pdf

1241 VanArsdale A., Weiss J., Keeler G., Miller E., Boulet G., Brulotte R. and Poissant L. (2005) Patterns of mercury deposition and concentration in Northeastern North America (19962002). Ecotoxicology 14, 37-52.

1244 Wang F., Tessier A. and Buffle J. (1998) Voltammetric determination of elemental sulfur in pore waters. Limnol. Oceanogr. 43, 1353-1361.

1246 Wang F. and Tessier A. (2009) Zero-valent sulfur and metal speciation in sediment porewaters of freshwater lakes. Environ. Sci. Technol. 43, 7252-7257.

Wedepohl K. H. (1995) The composition of the continental crust. Geochim. Cosmochim. Acta 59, 1249 $1217-1232$.

Winfrey M. R. and Rudd J. W. M. (1990) Environmental factors affecting the formation of methylmercury in low pH lakes. Environ. Toxicol. Chem. 9, 853-869.

1252 Xia K., Skyllberg U. L., Bleam W. F., Bloom P. R., Nater E. A. and Helmke P. A. (1999) X-ray absorption spectroscopic evidence for the complexation of $\mathrm{Hg}$ (II) by reduced sulfur in soil humic substances. Environ. Sci. Technol. 33, 257-261.

1255 Yang H., Battarbee R. W., Turner S. D., Rose N. L., Derwent R. G., Wu G. and Yang R. (2010) Historical reconstruction of mercury pollution across the Tibetan Plateau using lake sediments. Environ. Sci. Technol. 44, 2918-2924.

1258

1259 
1261 Table 1. Location and characteristics of the study lakes.

1262

\begin{tabular}{lcccc}
\hline Lake & \multicolumn{2}{c}{ Tantaré } & Bédard & Holland \\
& Basin A & \multicolumn{2}{c}{ Basin B } & \\
\hline Geographical coordinates & \multicolumn{2}{c}{$47^{\circ} 04^{\prime} \mathrm{N}$} & $47^{\circ} 16^{\prime} \mathrm{N}$ & $48^{\circ} 56^{\prime} \mathrm{N}$ \\
& \multicolumn{2}{c}{$71^{\circ} 32^{\prime} \mathrm{W}$} & $71^{\circ} 07^{\prime} \mathrm{W}$ & $65^{\circ} 23^{\prime} \mathrm{W}$ \\
Geological region & \multicolumn{2}{c}{ Can. Shield } & Can. Shield & Appalachian \\
Altitude $(\mathrm{m})$ & \multicolumn{2}{c}{450} & 680 & 475 \\
Lake area $\left(\mathrm{km}^{2}\right)$ & \multicolumn{2}{c}{1.1} & 0.045 & 0.008 \\
Watershed area $\left(\mathrm{km}^{2}\right)$ & \multicolumn{2}{c}{10.5} & 0.27 & 1.3 \\
Sampling depth $(\mathrm{m})$ & 15 & 22 & 10 & 11 \\
Redox state of bottom water & Perennially & Seasonally & Seasonally & Seasonally \\
& oxic & anoxic & anoxic & anoxic \\
Sampling dates & & & & \\
\multicolumn{1}{c}{ Coring } & June 03 & June 06 & Sept. 04 & August 05 \\
\multicolumn{1}{c}{ Porewater } & Sept. 05 & Sept. 06 & None & None \\
& Sept. 06 & July 07 & None & None \\
pH of bottom water & $5.5-5.8$ & $6.6-7.0$ & $6.9-7.0$ & $7.5-7.6$ \\
$\omega\left(\mathrm{mg} \mathrm{cm}^{-2} \mathrm{yr}^{-1}\right)^{\mathrm{a}}$ & $4.0-7.3$ & 10.8 & $2.4-46.8$ & $4.5-15.7$ \\
$v_{s}\left(\mathrm{~mm} \mathrm{yr}^{-1}\right)^{\mathrm{a}}$ & $0.9-1.3$ & $1.1-1.5$ & $0.5-2.6$ & $0.5-4.4$ \\
$I_{\text {Sed }}^{210 P b}\left(\mathrm{~Bq} \mathrm{~cm}^{-2}\right)^{\mathrm{a}}$ & 0.37 & 0.58 & 0.62 & 0.61 \\
\hline
\end{tabular}

${ }^{a}: \omega$ represents the sediment mass accumulation rate, $v_{s}$ the sedimentation rate and $I_{\text {Sed }}^{210 P b}$ the inventory of unsupported ${ }^{210} \mathrm{~Pb}$ in the sediment cores; the data were originally reported in Couture et al. (2008, 2010a). 
Table 2. Reactions and their corresponding equilibrium constants (at $25^{\circ} \mathrm{C}$ and ionic strength $=$ 0 ) used to update the WHAM 6 database. For the formation of polysulfides complexes, the equilibrium constants have been expressed in terms of dissolved zero-valent $\mathrm{S}$ using the reaction $1 / 8 \mathrm{~S}(\alpha)_{8(\mathrm{~s})}=\mathrm{S}(0)_{\mathrm{aq}} ; \log \mathrm{K}_{\mathrm{s}}=-6.68($ Wang and Tessier, 2009) .

1269

\begin{tabular}{|c|c|c|c|}
\hline No. & Reaction & Log K & References \\
\hline 1 & $\mathrm{Hg}^{2+}+\mathrm{OH}^{-}=\mathrm{HgOH}^{+}$ & 10.6 & Powell et al. (2005) \\
\hline 2 & $\mathrm{Hg}^{2+}+2 \mathrm{OH}^{-}=\mathrm{Hg}(\mathrm{OH})_{2}$ & 22.02 & Powell et al. (2005) \\
\hline 3 & $\mathrm{Hg}^{2+}+3 \mathrm{OH}^{-}=\mathrm{Hg}(\mathrm{OH})_{3}^{-}$ & 20.9 & Powell et al. (2005) \\
\hline 4 & $\mathrm{Hg}^{2+}+\mathrm{OH}^{-}+\mathrm{Cl}^{-}=\mathrm{HgOHCl}$ & 18.27 & Powell et al. (2005) \\
\hline 5 & $\mathrm{Hg}^{2+}+\mathrm{Cl}^{-}=\mathrm{HgCl}^{+}$ & 7.3 & Powell et al. (2005) \\
\hline 6 & $\mathrm{Hg}^{2+}+2 \mathrm{Cl}^{-}=\mathrm{HgCl}_{2}$ & 14.0 & Powell et al. (2005) \\
\hline 7 & $\mathrm{Hg}^{2+}+3 \mathrm{Cl}^{-}=\mathrm{HgCl}_{3}^{-}$ & 14.93 & Powell et al. (2005) \\
\hline 8 & $\mathrm{Hg}^{2+}+4 \mathrm{Cl}^{-}=\mathrm{HgCl}_{4}^{2-}$ & 15.5 & Powell et al. (2005) \\
\hline 9 & $\mathrm{Hg}^{2+}+\mathrm{SO}_{4}{ }^{2-}=\mathrm{HgSO}_{4}$ & 2.6 & Powell et al. (2005) \\
\hline 10 & $\mathrm{Hg}^{2+}+\mathrm{CO}_{3}^{2-}=\mathrm{HgCO}_{3}$ & 11.51 & Powell et al. (2005) \\
\hline 11 & $\mathrm{Hg}^{2+}+2 \mathrm{CO}_{3}{ }^{2-}=\mathrm{Hg}\left(\mathrm{CO}_{3}\right)_{2}{ }^{2-}$ & 15.58 & Martell et al. (2001) \\
\hline 12 & $\mathrm{Hg}^{2+}+\mathrm{OH}^{-}+\mathrm{CO}_{3}^{2-}=\mathrm{Hg}(\mathrm{OH}) \mathrm{CO}_{3}^{-}$ & 19.34 & Powell et al. (2005) \\
\hline 13 & $\mathrm{Hg}^{2+}+\mathrm{H}^{+}+\mathrm{CO}_{3}{ }^{2-}=\mathrm{HgHCO}_{3}^{+}$ & 15.84 & Powell et al. (2005) \\
\hline 14 & $\mathrm{Hg}^{2+}+\mathrm{HS}^{-}=\mathrm{HgSH}^{+}$ & 22.3 & Jay et al. (2000) \\
\hline 15 & $\mathrm{Hg}^{2+}+2 \mathrm{HS}^{-}=\mathrm{Hg}(\mathrm{SH})_{2}$ & 40.37 & Jay et al. (2000) \\
\hline 16 & $\mathrm{Hg}^{2+}+2 \mathrm{HS}^{-}+\mathrm{OH}^{-}=\mathrm{HgS}_{2} \mathrm{H}^{-}+\mathrm{H}_{2} \mathrm{O}$ & 48.6 & Jay et al. (2000) \\
\hline 17 & $\mathrm{Hg}^{2+}+2 \mathrm{HS}^{-}+2 \mathrm{OH}^{-}=\mathrm{HgS}_{2}{ }^{2-}+2 \mathrm{H}_{2} \mathrm{O}$ & 53.56 & Jay et al. (2000) \\
\hline 18 & $\mathrm{Hg}^{2+}+\mathrm{HS}^{-}+\mathrm{OH}^{-}=\mathrm{HgS}_{\mathrm{aq}}+\mathrm{H}_{2} \mathrm{O}$ & 43.8 & Jay et al. (2000) \\
\hline 19 & $\mathrm{Hg}^{2+}+\mathrm{HS}^{-}+2 \mathrm{OH}^{-}+4 \mathrm{~S}(0)=\mathrm{HgS}_{5} \mathrm{OH}^{-}+\mathrm{H}_{2} \mathrm{O}$ & 77.85 & Jay et al. (2000) \\
\hline 20 & $\mathrm{Hg}^{2+}+2 \mathrm{HS}^{-}+2 \mathrm{OH}^{-}+8 \mathrm{~S}(0)=\mathrm{Hg}\left(\mathrm{S}_{5}\right)_{2}{ }^{2-}+2 \mathrm{H}_{2} \mathrm{O}$ & 108.3 & Jay et al. (2000) \\
\hline 21 & $\mathrm{Hg}^{2+}+\mathrm{R}_{\mathrm{HA}}^{\mathrm{z}}=\mathrm{R}_{\mathrm{HA}} \mathrm{Hg}^{\mathrm{z}+2}$ & 3.6 & Tipping (2007) \\
\hline 22 & $\mathrm{Hg}^{2+}+\mathrm{R}_{\mathrm{FA}}^{\mathrm{z}}=\mathrm{R}_{\mathrm{FA}} \mathrm{Hg}^{\mathrm{z}+2}$ & 3.1 & Tipping (2007) \\
\hline 23 & $\mathrm{HgS}_{(\mathrm{s}, \text { cinnabar })}+\mathrm{H}^{+}=\mathrm{HS}^{-}+\mathrm{Hg}^{2+}$ & -39.1 & Martell et al. (2003) \\
\hline 24 & $\mathrm{HgO}_{(\mathrm{s})}+\mathrm{H}_{2} \mathrm{O}=\mathrm{Hg}^{2+}+2 \mathrm{OH}^{-}$ & -25.45 & Martell et al. (2003) \\
\hline 25 & $\mathrm{MeHg}^{+}+\mathrm{OH}^{-}=\mathrm{MeHgOH}$ & 9.47 & De Robertis et al. (1998) \\
\hline 26 & $2 \mathrm{MeHg}^{+}+\mathrm{OH}^{-}=(\mathrm{MeHg})_{2} \mathrm{OH}^{+}$ & 11.85 & De Robertis et al. (1998) \\
\hline 27 & $\mathrm{MeHg}^{+}+\mathrm{CO}_{3}{ }^{2-}=\mathrm{MeHgCO}_{3}^{-}$ & 6.1 & Rabenstein et al. (1976) \\
\hline 28 & $\mathrm{MeHg}^{+}+\mathrm{H}^{+}+\mathrm{CO}_{3}^{2-}=\mathrm{MeHgHCO}_{3}$ & 12.95 & Loux (2007) \\
\hline 29 & $\mathrm{MeHg}^{+}+\mathrm{Cl}^{-}=\mathrm{MeHgCl}$ & 5.45 & De Robertis et al. (1998) \\
\hline 30 & $\mathrm{MeHg}^{+}+\mathrm{SO}_{4}^{2-}=\mathrm{MeHgSO}_{4}^{-}$ & 2.64 & De Robertis et al. (1998) \\
\hline 31 & $\mathrm{MeHg}^{+}+\mathrm{HS}^{-}=\mathrm{MeHgSH}$ & 14.5 & Loux (2007) \\
\hline 32 & $\mathrm{MeHg}^{+}+\mathrm{HS}^{-}+\mathrm{OH}^{-}=\mathrm{MeHgS}^{-}+\mathrm{H}_{2} \mathrm{O}$ & 21.0 & Martell et al. (2001) \\
\hline 33 & $2 \mathrm{MeHg}^{+}+\mathrm{HS}^{-}+\mathrm{OH}^{-}=(\mathrm{MeHg})_{2} \mathrm{~S}+\mathrm{H}_{2} \mathrm{O}$ & 37.3 & Martell et al. (2001) \\
\hline 34 & $3 \mathrm{MeHg}^{+}+\mathrm{HS}^{-}+\mathrm{OH}^{-}=(\mathrm{MeHg})_{3} \mathrm{~S}^{+}+\mathrm{H}_{2} \mathrm{O}$ & 44.3 & Martell et al. (2001) \\
\hline 35 & $\mathrm{MeHg}^{+}+\mathrm{R}_{\mathrm{HA}}{ }^{\mathrm{z}}=\mathrm{R}_{\mathrm{HA}} \mathrm{MeHg}^{\mathrm{z+1}}$ & 0.3 & Tipping (2007) \\
\hline 36 & $\mathrm{MeHg}^{+}+\mathrm{R}_{\mathrm{FA}}^{\mathrm{z}}=\mathrm{R}_{\mathrm{FA}} \mathrm{MeHg}^{\mathrm{z}+1}$ & 0.3 & Tipping (2007) \\
\hline 37 & $\mathrm{FeS}\left(\right.$ s. mackinawite) $+\mathrm{H}^{+}=\mathrm{Fe}^{2+}+\mathrm{HS}^{-}$ & -3.5 & Rickard (2006) \\
\hline
\end{tabular}


1272 Table 3. Concentrations of $\mathrm{C}_{\text {org }}$, Fe-ox, $\mathrm{Hg}_{\mathrm{T}}$ and $\mathrm{MeHg}$ in the top 0.5-cm layer of Lake Tantaré 1273 Basin A sediments as well as molar ratios in this sediment layer and in the Fe-rich material 1274 collected with the Teflon sheets.

1275

\begin{tabular}{|c|c|c|}
\hline & \multicolumn{2}{|c|}{ Lake Tantaré Basin A } \\
\hline & Top sediment layer & Teflon sheets \\
\hline $\begin{array}{l}\text { Concentration } \\
\left\{\mathrm{C}_{\mathrm{org}}\right\} \mathrm{mol} \mathrm{C} \mathrm{g} \\
\{\mathrm{Fe}-\mathrm{ox}\} \mathrm{mol} \mathrm{g}^{-1} \\
\left\{\mathrm{Hg}_{\mathrm{T}}\right\} \mathrm{mol} \mathrm{g}^{-1} \\
\{\mathrm{MeHg}\} \mathrm{mol} \mathrm{g}^{-1}\end{array}$ & $\begin{array}{c}2.02 \pm 0.08 \times 10^{-2} \\
1.55 \pm 0.05 \times 10^{-3} \\
3.0 \pm 0.1 \times 10^{-9} \\
7.6 \pm 1.1 \times 10^{-11}\end{array}$ & \\
\hline $\begin{array}{l}\text { Molar ratio } \\
\left\{\mathrm{C}_{\text {org }}\right\}:\{\mathrm{Fe}-\mathrm{ox}\} \\
\left\{\mathrm{C}_{\text {org }}\right\}:\{\mathrm{N}\} \\
\left\{\mathrm{Hg}_{\mathrm{T}}\right\}:\{\mathrm{Fe}-\mathrm{ox}\} \\
\{\mathrm{MeHg}\}:\{\mathrm{Fe}-\mathrm{ox}\} \\
\left\{\mathrm{Hg}_{\mathrm{T}}\right\}:\left\{\mathrm{C}_{\text {org }}\right\} \\
\{\mathrm{MeHg}\}:\left\{\mathrm{C}_{\text {org }}\right\}\end{array}$ & $\begin{array}{c}13 \\
15.5 \\
1.9 \times 10^{-6} \\
4.9 \times 10^{-8} \\
1.5 \times 10^{-7} \\
3.8 \times 10^{-9}\end{array}$ & $\begin{array}{c}2.6 \pm 0.3 \\
15.3 \pm 3.4 \\
1.3 \pm 0.3 \times 10^{-7} \\
6.5 \pm 1.9 \times 10^{-10} \\
4.9 \pm 0.7 \times 10^{-8} \\
2.5 \pm 0.6 \times 10^{-10} \\
\end{array}$ \\
\hline
\end{tabular}

1276

1277 
1278 Table 4. $R_{\text {net }}^{H g}$ as a function of depth calculated with the computer code PROFILE for each of the 1279 two study basins of Lake Tantaré and sampling date along with estimated present-day fluxes of $\mathrm{Hg}$ 1280 due to particle settling ( $J_{\text {Dep }}^{H g}$ ) and to the transport of dissolved $\mathrm{Hg}$ across the sediment-water 1281 interface by molecular diffusion $\left(J_{D}^{\mathrm{Hg}}\right)$, bioirrigation $\left(J_{I}^{\mathrm{Hg}}\right)$, and biodiffusion $\left(J_{B}^{\mathrm{Hg}}\right)$, and net $\mathrm{Hg}$ 1282 accumulation fluxes $\left(J_{A c c}^{H g}\right)$.

1283

\begin{tabular}{|c|c|c|c|c|c|c|c|c|}
\hline \multirow{2}{*}{$\begin{array}{c}\text { Sampling } \\
\text { Date }\end{array}$} & \multirow{2}{*}{$\begin{array}{c}\text { Zone } \\
\text { No. }\end{array}$} & \multirow{2}{*}{$\begin{array}{c}\text { Depth } \\
\text { interval } \\
\mathrm{cm} \\
\end{array}$} & \multirow{3}{*}{$\begin{array}{c}R_{\text {net }}^{H g} \\
10^{-21} \mathrm{~mol} \mathrm{~cm}^{-3} \mathrm{~s}^{-1} \\
\end{array}$} & $J_{\text {Dep }}^{H g}$ & $J_{D}^{H g}$ & $J_{I}^{H g}$ & $J_{B}^{H g}$ & $J_{A c c}^{H g}$ \\
\hline & & & & \multicolumn{5}{|c|}{$10^{-21} \mathrm{~mol} \mathrm{~cm}^{-2} \mathrm{~s}^{-1}$} \\
\hline \multirow{3}{*}{$\begin{array}{l}\text { Basin A } \\
\text { Sept. 05 }\end{array}$} & & & & & & & & \\
\hline & 1 & $0-6.3$ & -0.7 & 544 & 0.95 & 0.27 & $4.3 \times 10^{-4}$ & 545 \\
\hline & 2 & $6.33-9.5$ & 2.4 & & & & & \\
\hline Sept. 06 & 1 & $0-9.5$ & -0.8 & 544 & 0.24 & 0.058 & $1.1 \times 10^{-4}$ & 544 \\
\hline \multicolumn{9}{|l|}{ Basin B } \\
\hline \multirow[t]{2}{*}{ Oct. 06} & 1 & $0-4.1$ & -14 & 765 & 65.8 & 0 & 0 & 821 \\
\hline & 2 & $4.1-9.5$ & 1.7 & & & & & \\
\hline \multirow[t]{2}{*}{ July 07} & 1 & $0-5.7$ & -3.6 & 765 & 18.6 & 0 & 0 & 784 \\
\hline & 2 & $5.7-8.5$ & 11 & & & & & \\
\hline
\end{tabular}

1284 
Table 5. $R_{n e t}^{\mathrm{MeHg}}$ as a function of depth calculated with the computer code PROFILE for each of the 1288 two study basins of Lake Tantaré and sampling date along with estimated present-day fluxes of $1289 \mathrm{MeHg}$ due to particle settling ( $J_{\mathrm{Dep}}^{\mathrm{MeH}}$ ) and to the transport of dissolved MeHg across the 1290 sediment-water interface by molecular diffusion $\left(J_{D}^{\mathrm{MeHg}}\right)$, bioirrigation $\left(J_{I}^{\mathrm{MeHg}}\right)$, and biodiffusion $1291\left(J_{B}^{\mathrm{MeHg}}\right)$, and net MeHg accumulation fluxes $\left(J_{A c c}^{\mathrm{MeHg}}\right)$. To estimate $J_{D e p}^{\mathrm{MeHg}}$, we assumed that the 1292 production or degradation of $\mathrm{MeHg}$ in surface sediments is negligible.

1293

\begin{tabular}{|c|c|c|c|c|c|c|c|c|}
\hline \multirow{2}{*}{$\begin{array}{c}\text { Sampling } \\
\text { Date }\end{array}$} & \multirow{2}{*}{$\begin{array}{l}\text { Zone } \\
\text { No. }\end{array}$} & \multirow{2}{*}{$\begin{array}{l}\text { Depth } \\
\text { interval } \\
\mathrm{cm}\end{array}$} & \multirow{2}{*}{$\begin{array}{c}R_{n e t}^{\mathrm{MeHg}} \\
10^{-21} \mathrm{~mol} \mathrm{~cm}^{-3} \mathrm{~s}^{-1}\end{array}$} & $J_{\text {Dep }}^{\mathrm{MeHg}}$ & $J_{D}^{\mathrm{MeHg}}$ & $J_{I}^{\mathrm{MeHg}}$ & $J_{B}^{\mathrm{MeHg}}$ & $J_{A c c}^{\mathrm{MeHg}}$ \\
\hline & & & & \multicolumn{5}{|c|}{$10^{-21} \mathrm{~mol} \mathrm{~cm}^{-2} \mathrm{~s}^{-1}$} \\
\hline \multirow{3}{*}{$\begin{array}{l}\text { Basin A } \\
\text { Sept. } 05\end{array}$} & & & & & & & & \\
\hline & 1 & $0-4.7$ & -0.2 & 14.1 & 0.20 & 0.020 & $0.7 \times 10^{-4}$ & 14.3 \\
\hline & 2 & $4.7-9.5$ & 0.3 & & & & & \\
\hline \multirow[t]{4}{*}{ Sept.06 } & 1 & $0-1.2$ & -1.1 & 14.1 & -0.39 & -0.099 & $-1.4 \times 10^{-4}$ & 13.6 \\
\hline & 2 & $1.2-2.4$ & 2.1 & & & & & \\
\hline & 3 & $2.4-5.9$ & -0.3 & & & & & \\
\hline & 4 & $5.9-9.5$ & 0.1 & & & & & \\
\hline \multicolumn{9}{|l|}{ Basin B } \\
\hline \multirow[t]{2}{*}{ Oct. 06} & 1 & $0-1.6$ & -3.5 & 4.65 & 5.70 & 0 & 0 & 10.3 \\
\hline & 2 & $1.6-9.5$ & -0.01 & & & & & \\
\hline \multirow[t]{2}{*}{ July 07} & 1 & $0-3.2$ & -0.9 & 4.65 & 4.05 & 0 & 0 & 8.7 \\
\hline & 2 & $3.2-9.5$ & -0.03 & & & & & \\
\hline
\end{tabular}


Figure 1. Location map of Lakes Tantaré, Bédard and Holland. Inset: Lake Tantaré and its watershed, including the sampling location in Basins A and B.

1301

Figure 2. Triplicate porewater profiles of $\mathrm{Hg}_{\mathrm{T}}(\mathrm{a}-\mathrm{d}), \mathrm{MeHg}(\mathrm{e}-\mathrm{h}), \mathrm{Fe}$ and $\mathrm{Mn}(\mathrm{i}-1), \Sigma \mathrm{S}(-\mathrm{II})(\mathrm{m}-\mathrm{p})$, $\Sigma \mathrm{S}(0)(\mathrm{q}-\mathrm{t})$, and $\mathrm{SO}_{4}(\mathrm{u}-\mathrm{x})$ concentrations for Basin A of Lake Tantaré in September 2005 and in

1304 September 2006 and for Basin B of Lake Tantaré in October 2006 (anoxic period) and in July 2007 1305 (oxic period). The circle, triangle and square symbols are for triplicate water samples for either the measurements of $\mathrm{Hg}_{\mathrm{T}}, \mathrm{MeHg}, \mathrm{Fe}$ and $\mathrm{Mn}$ or those of $\sum \mathrm{S}(-\mathrm{II}), \sum \mathrm{S}(0)$, and $\mathrm{SO}_{4}$. Empty symbols in panels a-h and $\mathrm{m}-\mathrm{t}$ represent concentrations below detection limit. The horizontal dotted lines indicate the sediment-water interface.

Figure 3. Depth profiles of the main species of dissolved $\mathrm{Hg}_{\mathrm{NM}}(\mathrm{a}-\mathrm{d})$ and of dissolved $\mathrm{MeHg}(\mathrm{e}-\mathrm{h})$

1311 for Lake Tantaré Basins A and B. The percentages of the dissolved species of inorganic $\mathrm{Hg}$ and

1312 MeHg were calculated with the speciation model WHAM 6. Comparison of modeled and

1313 measured average $(\mathrm{n}=3)$ concentration of dissolved $\mathrm{Hg}_{\mathrm{T}}(\mathrm{i}-\mathrm{l})$ and $\mathrm{MeHg}(\mathrm{m}-\mathrm{p})$ with the horizontal

1314 dotted lines indicating the sediment-water interface, the piecewise constant functions (thick solid

1315 lines) representing the net $\mathrm{Hg}_{\mathrm{T}}$ and $\mathrm{MeHg}$ production (+) /consumption (-) rate $\left(R_{\text {net }}^{\mathrm{Hg}}\right.$ and $\left.R_{\text {net }}^{\mathrm{MeHg}}\right)$

1316 and the thin solid lines following the measured values showing the PROFILE model fitting.

1317 Saturation index $\left(\mathrm{SI}=\log \left(\mathrm{IAP}_{\mathrm{K}} / \mathrm{K}_{\mathrm{s}}\right)\right.$ profiles for $\mathrm{FeS}_{(\mathrm{s}, \mathrm{m})}\left(\right.$ disordered mackinawite; $\left.\mathrm{K}_{\mathrm{s}}=-3.5\right)$ is also 1318 given $(\mathrm{q}-\mathrm{t})$. 
1320 Figure 4. Depth profiles of $\left\{\mathrm{Hg}_{\mathrm{T}}\right\}$ and $\left\{\mathrm{Hg}_{\mathrm{T}}\right\}:\{\mathrm{Al}\}$ molar ratio (a-d), $\{\mathrm{MeHg}\}$ (e-f), $\{\mathrm{Fe}\}$ and

$1321\{\mathrm{Mn}\}(\mathrm{g}-\mathrm{j}),\left\{\mathrm{C}_{\mathrm{org}}\right\}(\mathrm{k}-\mathrm{n})$, and $\left\{\mathrm{S}_{\mathrm{T}}\right\}$ and $\{\mathrm{AVS}\}(\mathrm{o}-\mathrm{r})$ in Lake Tantaré Basins $\mathrm{A}$ and $\mathrm{B}$ and in Lakes 1322 Bédard and Holland.

1323

1324 Figure 5. Comparison of modeled and measured concentration of dissolved $\mathrm{MeHg}$ (a-c) for Basin 1325 A in September 2006 with the horizontal dotted lines indicating the sediment-water interface, the 1326 piecewise constant functions (thick solid lines) representing the net MeHg production (+)

1327 /consumption (-) rate $\left(R_{n e t}^{M e H g}\right)$ and the thin solid lines following the measured values showing the 1328 PROFILE model fitting.

1329

1330 Figure 6. Reconstructed historical records of anthropogenic $\mathrm{Hg}$ deposition fluxes to the sediments 1331 of Lake Tantaré (a) Basins A (filled circles) and B (open circles), of Lake Bédard (b) and of Lake 1332 Holland (c) corrected for lake specific processes $\left(J_{C o r r}^{H g-A n t h}\right)$; the insets show the records uncorrected for such processes $\left(J^{H g-A n t h}\right)$. 


$$
\text { FIGURES - Feyte et al. }
$$

2

3

Mercury dynamics in lake sediments 


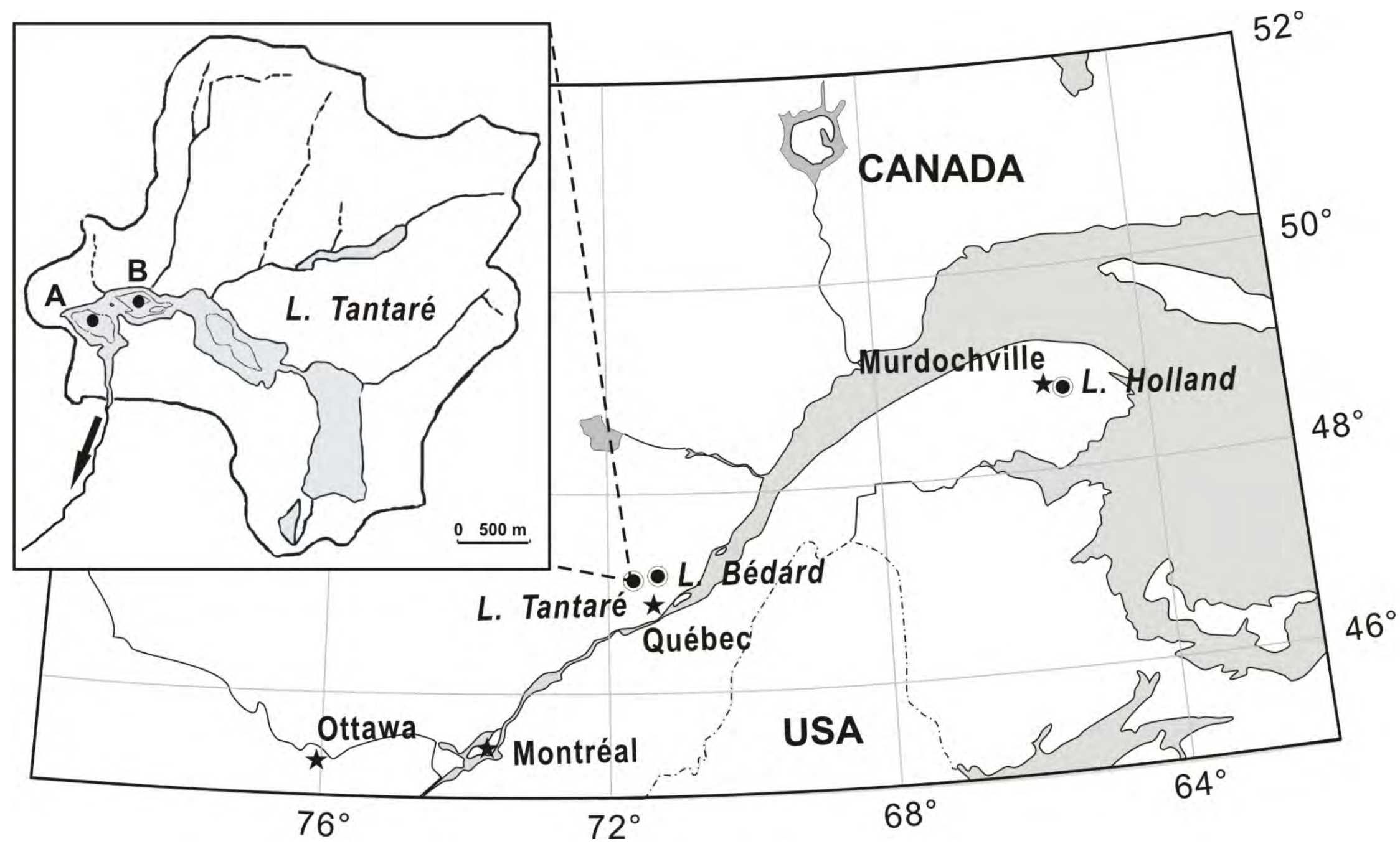

Fig. 1 

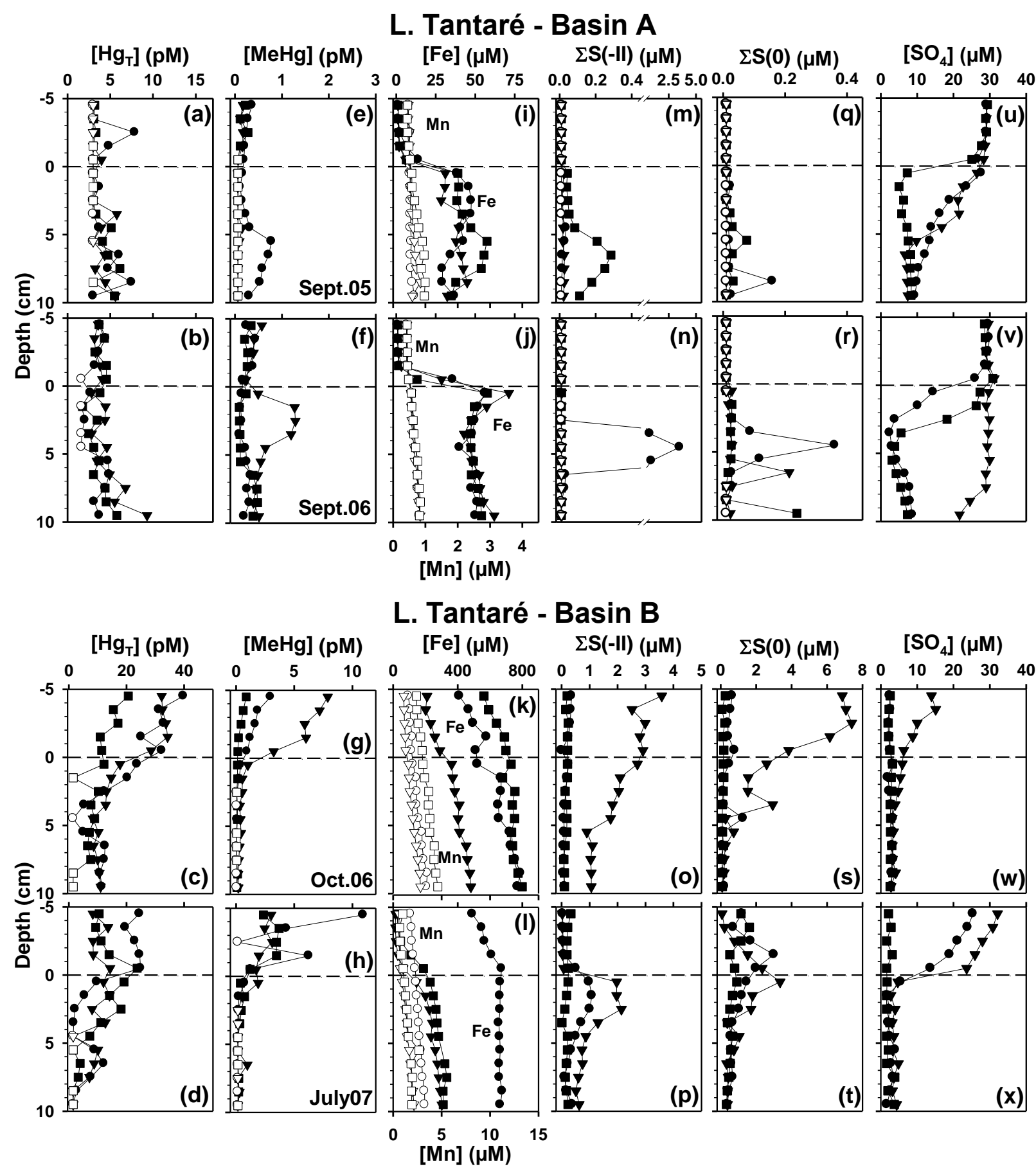

Fig. 2 

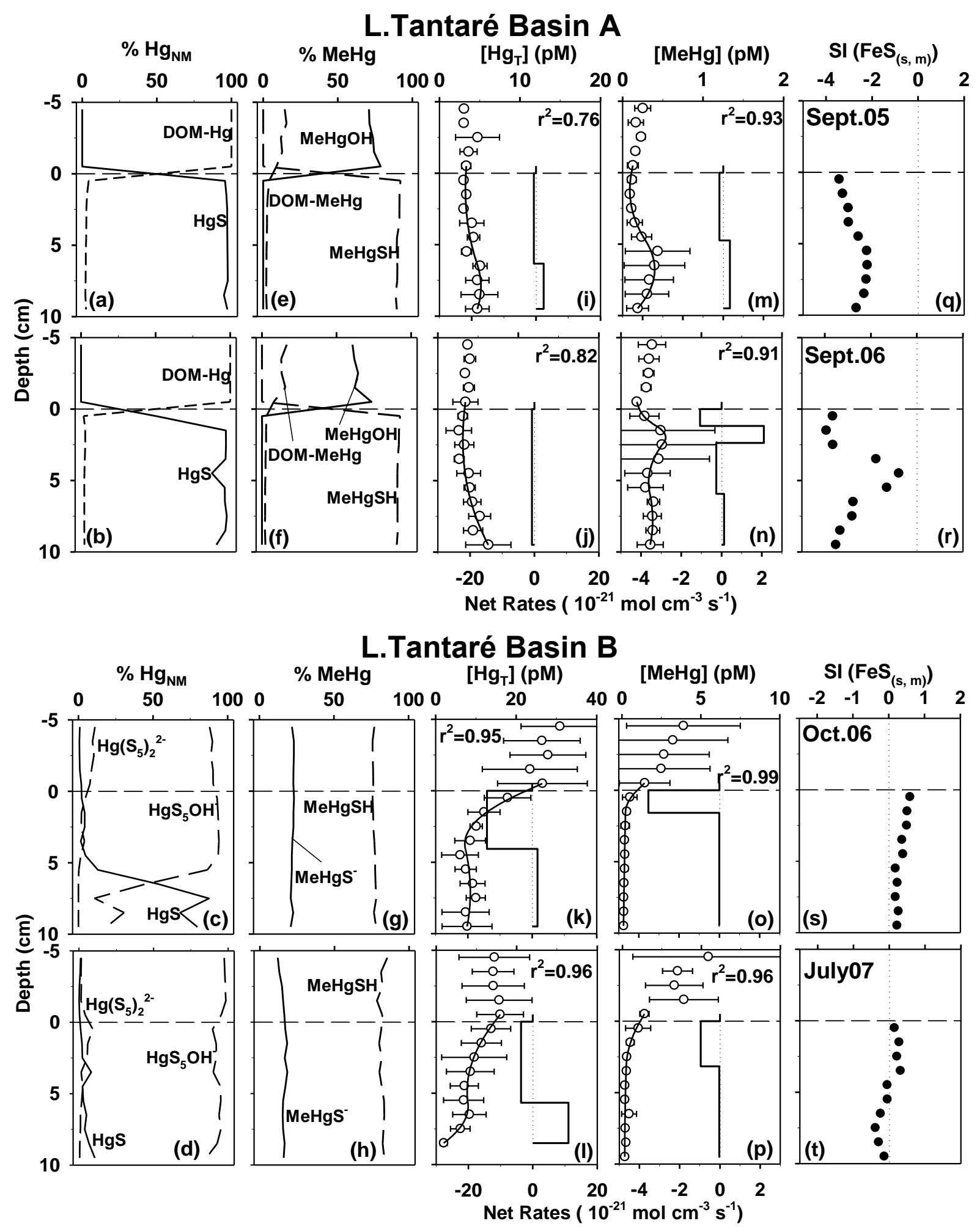

Fig. 3 


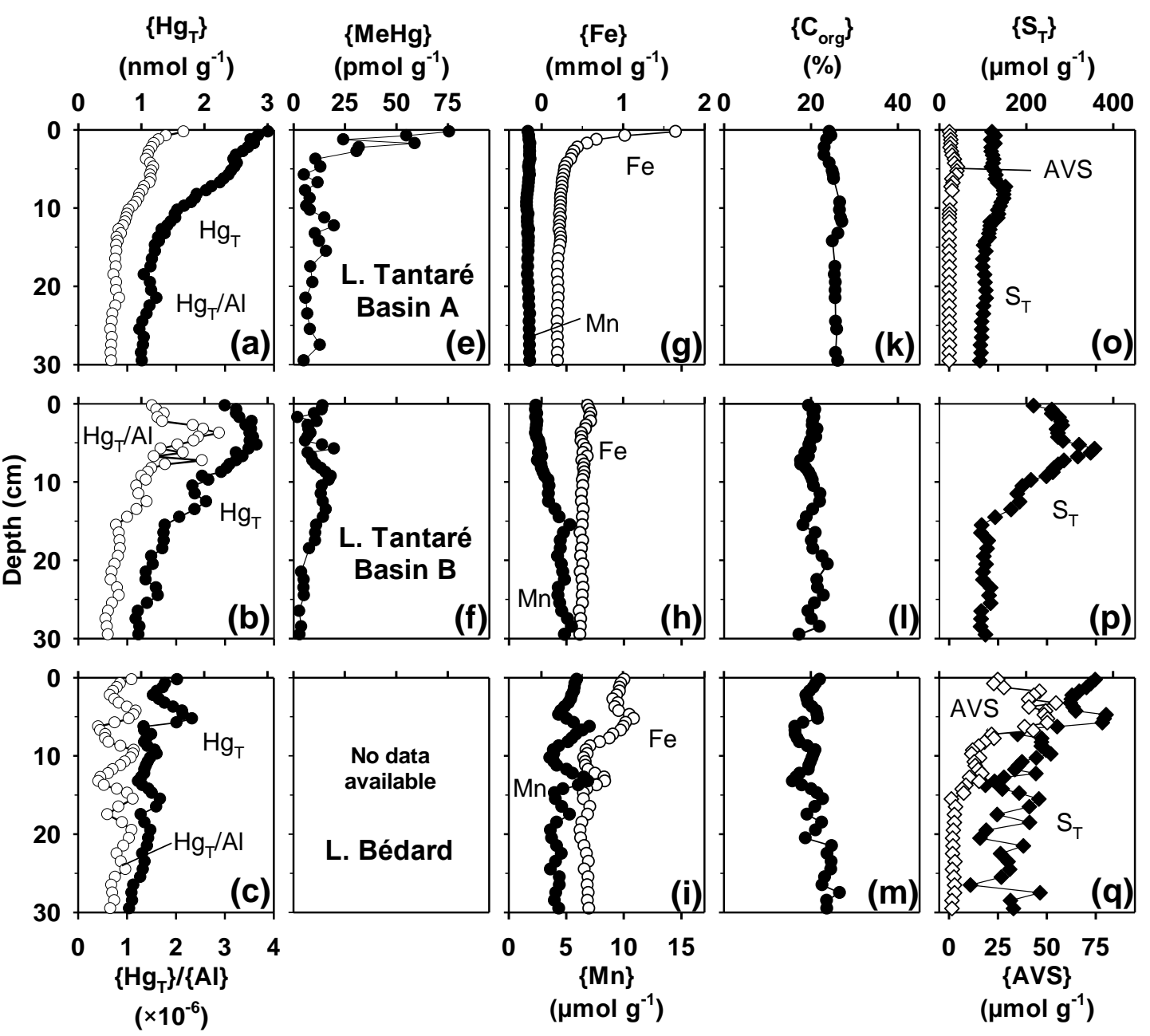

$\left\{\mathrm{Hg}_{\mathrm{T}}\right\}$

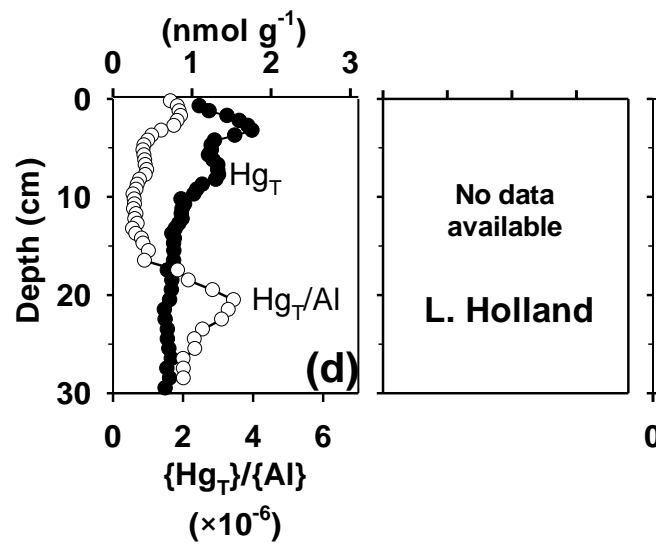

$\{\mathrm{Fe}\}$

$\left(\mathrm{mmol} \mathrm{g}^{-1}\right)$ $\begin{array}{lll}0.0 & 0.5 & 1.0\end{array}$

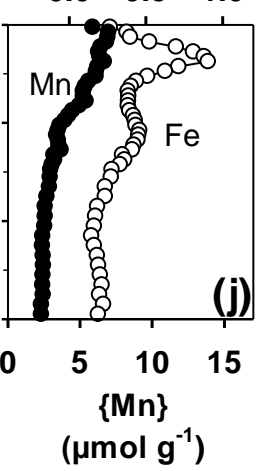

$\left\{S_{T}\right\}$

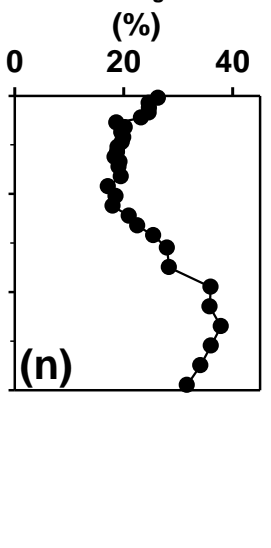

$\left(\mu \mathrm{mol} \mathrm{g}{ }^{-1}\right)$

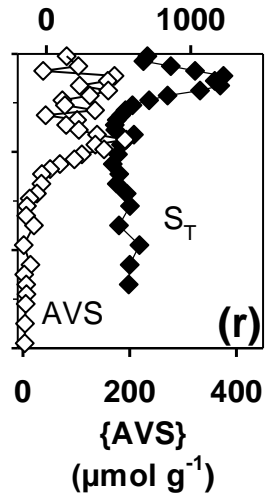

Fig. 4 


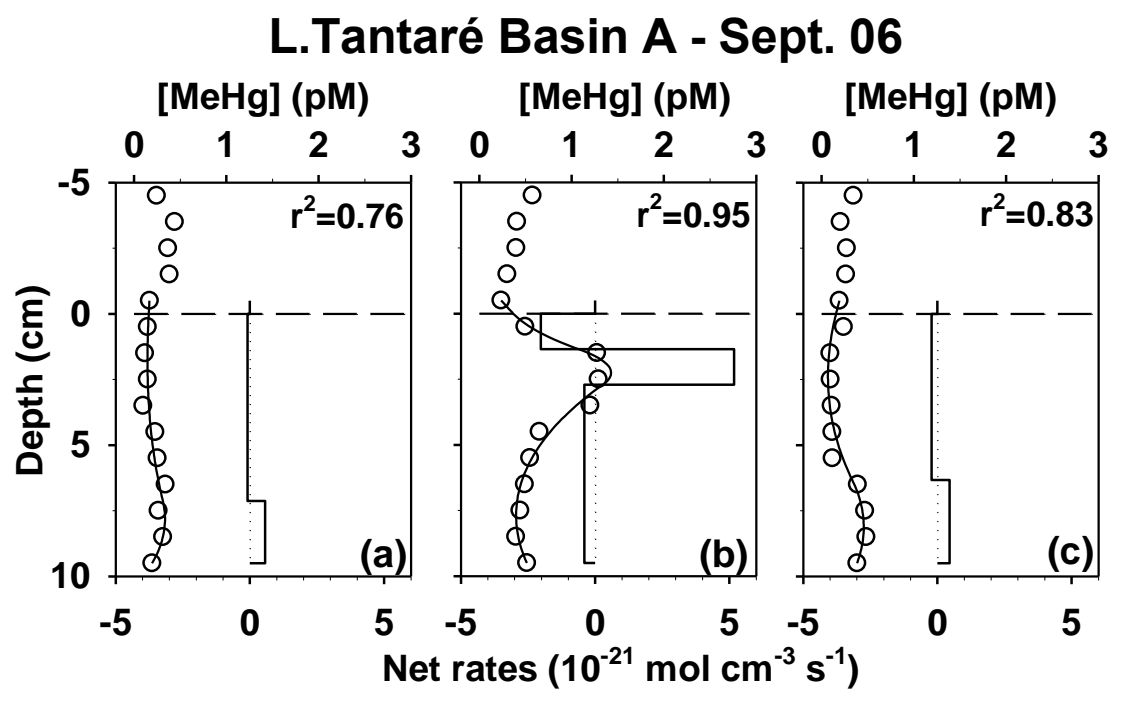

Fig. 5 

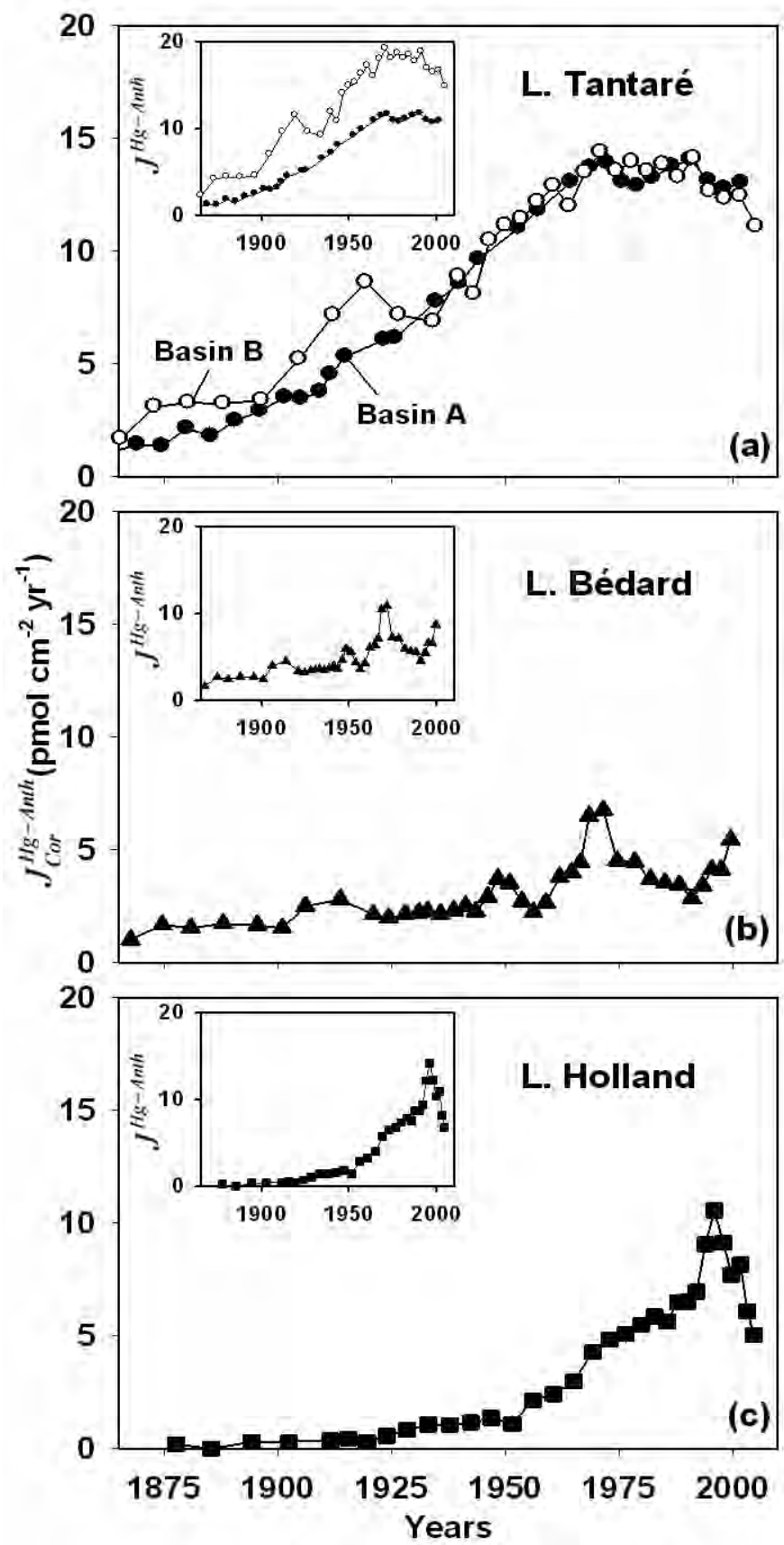

Fig. 6 